\title{
ALGUNOS ASPECTOS DEL PONTIFICADO DE MONS. ILUNDAIN Y ESTEBAN EN OURENSE A LA LUZ DE LOS ARCHIVOS VATICANOS (1905-1921)
}

\author{
JOSÉ RAMÓN HERNÁNDEZ FIGUEIREDO \\ Instituto Teológico del «Divino Maestro» de Ourense
}

\begin{abstract}
Resumen
Ourense en los inicios del siglo XX, aún siendo una sociedad eminentemente agraria y tradicional, vive y participa en todos los problemas del momento, a nivel social, político y eclesial. La Iglesia diocesana vive la preocupación general de la Iglesia con su posicionamiento ante las corrientes liberales y modernistas. El anticlericalismo brota por momentos y es aprovechado políticamente en hechos como el caso de Oseira, para atacar a la Iglesia en la persona del obispo. Los inéditos fondos vaticanos ofrecen valiosa información para conocer las luces y las sombras del pontificado de mons. Ilundain y Esteban. Su espíritu reformador del clero y de la grey lo sitúan como uno de los grandes obispos de Ourense y uno de los prelados más completos y cabales del conjunto del episcopado español del primer tercio del siglo XX.
\end{abstract}

\section{Palabras claves}

Ilundain, liberalismo, anticlericalismo, reforma, clero, parroquias.

\section{Summary}

Ourense in the early XX century, although being a mainly agricultural and traditional society, lives and participates in all the problems of the moment in the political, social and ecclesiastical levels. The diocesan Church lives the general worry of the Church with its position in the face of the liberal and modernist positions. The anticlericalism springs up by the minute and it is politically used in facts like the case of Oseira for attacking the Church in the person of the bishop. The previously unknown files of the Vatican offer valuable information for knowing the lights and shadows of the papacy of monseigneur Ilundain y Esteban. His reforming spirit of the priesthood and the churchgoers situates him as one of the big bishops of Ourense and one of the most complete and fine prelates in the whole of the Spanish episcopate of the first third of the XX century.

\section{Key words}

Ilundain, Liberalism, Anticlericalism, Reform, Clergy, Parish church. 


\section{INTRODUCCIÓN}

Ourense, a comienzos del siglo XX, se caracteriza por ser una sociedad eminentemente agraria y tradicional, que vive y participa en todos los problemas del momento, a nivel social, político y eclesial. El fracaso político se traduce en olvido y falta de desarrollo para el mundo rural especialmente. Los viejos foros, elementos del antiguo régimen, entran en conflicto con las nuevas leyes liberales en la Galicia rural, en la que el minifundismo y una agricultura atrasada y ruinosa no abrían puerta ninguna para salir de esa situación. Tampoco cuando se produjo la desamortización en absoluto redundó ésta en beneficio de los campesinos, pues simplemente las rentas de esos bienes pasaron a manos de la burguesía urbana y a profesionales liberales ${ }^{1}$.

La única salida a la pobreza y miseria es la emigración a América que debilita enormemente a Ourense, dándose los más altos saldos migratorios en las zonas de Carballiño y Celanova ${ }^{2}$. La inquietud social se manifiesta, en parte organizadamente, en el movimiento agrarista, en el que el cura Basilio Álvarez tuvo un papel destacado $^{3}$. La Iglesia diocesana vive la preocupación general de la Iglesia con su posicionamiento ante las corrientes liberales y modernistas. El anticlericalismo brota por momentos y es aprovechado políticamente en hechos como el caso de Oseira, tal como veremos, para atacar a la Iglesia en la persona del obispo. A pesar de todos estos agravantes y condicionantes, don Eustaquio se convierte en uno de los grandes obispos de Ourense y uno de los prelados más completos y cabales del conjunto del episcopado español del primer tercio del siglo XX.

La principal fuente de estudio es la obra elaborada por el familiar del prelado, canónigo de la iglesia metropolitana de Sevilla, el Dr. D. Laureano Tovar González, testigo ocular por más de treinta y dos años del egregio purpurado, quien estando bien informado, nos ofrece una de las contadas monografías de carácter biográfico que se han escrito sobre cardenales españoles en nuestra era contemporánea. Riguroso y exuberante en los datos que ofrece, adolece sin embargo de cierta crítica y objetividad, si se tiene en cuenta la familiaridad del biógrafo y el

${ }^{1}$ Xosé Ramón Barreiro FernándeZ, Historia de Galicia, IV: edade contemporánea, Vigo 1981, pp. 17-38.

${ }^{2}$ Ricardo Villares, Edad contemporánea, en Historia de Galicia, Madrid 1981, pp. 235-237.

${ }^{3}$ ASV, Arch. Nunz. Madrid, busta 734, pos. 84, ff. 6r-30r, que recoge un legajo de correspondencia titulado: «Mons. Vescovo di Orense e le Opere Sociali di Basilio Alvarez». A continuación también aparecen algunos recortes de prensa: Correspondencia de España, 22 de febrero de 1914; El País, 22 de febrero de 1914; La Tribuna, n. 750 (22 febrero 1914), p. 2; El Radical, n. ${ }^{\circ} 1408$ (22 febrero 1914), p. 1. 
biografiado, además de la proximidad temporal entre la muerte del finado cardenal y la publicación de esta obra. Transcurren apenas cinco años, entre 1937 y $1942^{4}$.

En un segundo lugar, también merecen señalarse otras dos síntesis biográficas, refiriéndose más la primera a su etapa como obispo auriense, y la segunda como arzobispo hispalense ${ }^{5}$. Ahora bien, si los arroyos son graciosos y cristalinos y el viajero se siente deliciosamente refrigerado cuando aproxima a ellos sus labios abrasados por el calor y el cansancio, ¿cuánto más bella y benéfica será la misma fuente de donde proceden? Es decir, teniendo al alcance documentos inéditos y de primera mano, ¿cómo contentarnos con las impresiones pasadas por el tamiz del que biografía? Siguiendo este raciocinio, me he animado a hilvanar la abundante documentación encontrada en los fondos de Nunciatura de Madrid, Secretaría de Estado y Congregación del Concilio del Archivio Segreto Vaticano, para dibujar desde otra perspectiva una nueva semblanza sobre la persona y actuación de tan meritorio prelado auriense.

Además, soy plenamente consciente de que las fuentes archivísticas sobre nuestro personaje son mucho más abundantes, incluso si nos atenemos a las que provienen de nuestra diócesis de As Burgas, custodiadas principalmente en los archivos capitular y diocesano. Por mi parte, he tenido la oportunidad de ordenar e inventariar numerosos legajos de documentación administrativa y correspondencia varia que evidencian la trascendencia de su paso por nuestra diócesis. En este sentido, basta aproximarnos a cualquier archivo parroquial de las setecientas feligresías que componen el mapa geográfico ourensano, para darnos cuenta de la incidencia y fecundidad de su ministerio episcopal. Sin embargo, para la elaboración del presente artículo, acotaremos el objeto de estudio a la documentación vaticana que nos permita esbozar algunos aspectos de su pontificado: el complejo proceso de su elección episcopal, la reforma del clero mediante un sínodo diocesano, y el padecimiento de un liberalismo hostil en el ejercicio pastoral de su grey en algunas parroquias aurienses.

\footnotetext{
${ }^{4}$ Laureano Tovar González, Ensayo biográfico del Emmo. Señor Cardenal Ilundain y Esteban, Obispo que fue de Orense y Arzobispo de Sevilla, Pamplona: Editorial Aramburu, 1942.

${ }_{5}^{5}$ Miguel Ángel González García, La diócesis de Orense desde 1850, en Historia de las diócesis españolas, XV: Iglesias de Lugo, Mondoñedo-Ferrol y Orense, ed. José GARCÍA Oro, Madrid: BAC, 2002, pp. 567-573, y Carlos Ros, Los Arzobispos de Sevilla. Luces y sombras en la sede hispalense, Sevilla: Ed. Anel, 1986, pp. 278-282.
} 


\section{ELECCIÓN DEL OBISPO}

Mons. Ilundain nace en septiembre de 1862, en la ciudad de Pamplona en el seno de una familia de clase media desahogada y de hondas convicciones religiosas. En 1873 acude a una preceptoría de latín llevada por un profesor seglar, ya que el seminario se encuentra cerrado a causa de la guerra carlista. Al año siguiente ingresa en el noviciado de los carmelitas de Begoña (Bilbao), pero sale a los pocos meses. Vuelve a Pamplona donde cursa los estudios eclesiásticos de gramática, filosofía y teología en el seminario de esa ciudad ${ }^{6}$, y el derecho canónico en el seminario de Santo Tomás de Aquino de Ciudad Real, destacando siempre con las máximas calificaciones. En 1884, siendo estudiante de cuarto de Teología, es nombrado profesor pasante de teodicea, ética y derecho natural, además de catedrático de metafísica especial. Desde entonces hasta su promoción al sacerdocio en 1886, se ejercita con celo e infatigable actividad en las tareas del sagrado ministerio.

$\mathrm{Al}$ año siguiente, pasa a Toledo para graduarse en Teología. Sigue aprovechando las vacaciones para acercarse con frecuencia a predicar y confesar en varias parroquias rurales de su diócesis, instituyendo la pía asociación del Apostolado de la Oración. También la funda en 1889 en el seminario de Pamplona, siendo su primer presidente. En 1890 la Corona lo nombra canónigo magistral de Ciudad Real, y en su seminario el obispo prior le confía la cátedra de teología dogmática, materia que explica por espacio de doce años, llegando a ser rector del mismo en 1901. También asume la dirección espiritual de comunidades religiosas y pías asociaciones $^{7}$. Entonces compone un librito Curso espiritual del seminarista, obra muy apreciada, que tiene mucho éxito y cuenta con cuatro ediciones ${ }^{8}$.

\footnotetext{
${ }^{6}$ Sobre el seminario de Pamplona puede verse la modélica monografía de Antón M. PAzos RodríGUEZ, Origen y formación del clero navarro 1900-1936, Pamplona: Eunsa, 1991.

${ }^{7}$ Proposta di candidati per varie Sedi Vescovili vacanti. Madrid 9 giugno 1904, en ASV, Segr. Stato, 1904, 249, fasc. 1, f. 141r-v (n. ${ }^{\circ}$ protocolo 6782). Datos enviados por el nuncio apostólico de Madrid al secretario de estado del Vaticano.

${ }^{8}$ Eustaquio ILUNDAIN y ESTEBAN, Curso espiritual del seminarista que anhela la santificación propia de su vocación eclesiástica mediante el ejercicio de la piedad sólida, Madrid: Imprenta De San Francisco de Sales, 1899. Como mera curiosidad, quiero hacer notar que el ejemplar consultado es el que se guarda en la biblioteca del Pontificio Colegio Español de San José, y éste aparece dedicado por el autor al rector del mencionado Colegio cuando ocupaba ese mismo cargo en el seminario de Ciudad Real. De esto se presume como estaba al quite de los grandes eventos reformadores de la enseñanza eclesiástica española y se movía en aquellos ambientes de espíritu innovador. Fue libro de adquisición obligada para los seminaristas hasta los años cincuenta.
} 


\subsection{Para Canarias}

En 1903 pasa a Segovia como arcipreste de la catedral y rector del seminario, tras el máximo interés mostrado por el obispo de esta diócesis castellana, don José Cadena y Eleta. A finales de aquel primer curso 1903-1904, se retira en la casa de San Gabriel de los PP. Misioneros, situada a las afueras de la ciudad de Segovia, para recibir ejercicios espirituales. Mientras tanto, llega al Seminario Conciliar una carta con el sello de franquicia del Ministerio de Gracia y Justicia. En la misma, el Sr. Ministro don Joaquín Sánchez de Toca le expresa la conveniencia de que la sede vacante de Canarias sea provista por su persona.

Esta propuesta es apoyada personalmente por el obispo de Segovia, quien no se guarda celosamente a este presbítero para su diócesis, sino que lo pone a disposición de un servicio eclesial, más universal. Al respecto, emite el siguiente juicio que es parte del informe secreto enviado al nuncio apostólico de Madrid:

«creo que reune las condiciones de ciencia, prudencia y virtud y las dotes necesarias de gobierno para ser un buen Obispo. Es Doctor en Sagrada Teología y tiene ademas la carrera de Cánones. Le conozco hace ya muchos años y siempre ha merecido mi mayor aprecio por su virtud y excelentes cualidades. Por eso y porque creí tener en él un poderoso auxiliar, como así ha sucedido, lo nombré Arcipreste de esta Catedral, Rector del Seminario diocesano y Director de la Asociación del Sagrado Corazón de Jesús, de cuyos nombramientos estoy cada día más satisfecho, y cuando me ausento de la Diócesis le confío el gobierno de la misma»?.

$\mathrm{Al}$ respecto, es interesante ver la honda amistad y confianza que une a nuestro biografiado con el prelado segoviano, haciéndole saber que una vez conocida la referida propuesta, llegó a pasar una «noche nada tranquila» y que tras consultar este asunto in foro conscientiae con el Padre más grave de la casa donde hacía ejercicios, consideró que no era despropósito rehusar el cargo en cuestión y que acaso fuera temerario aceptarlo, decidiendo escribir al ministro y al nuncio la comunicación de su renuncia formal y definitiva ${ }^{10}$.

\footnotetext{
${ }^{9}$ Proposta di candidati per varie Sedi Vescovili vacanti. Madrid 9 giugno 1904, en ASV, Segr. Stato, 1904, 249, fasc. 1, f. 142r.

${ }^{10}$ Carta del presbítero Ilundain al nuncio apostólico de Madrid. Segovia, 23 de junio de 1904, en ASV, Arch. Nunz. Madrid, busta 659, tit. VII, rub. II, sez. I, n. ${ }^{\circ} 20$, f. 253r: «habiendo recibido ayer carta del Excmo. Sr. Ministro de Gracia y Justicia, pidiendo de acuerdo con S. E. Rma. mi consentimiento para el caso en que S. M. tuviese á bien presentarme á S. S. para la Silla Episcopal de Canarias, he creido oportuno después de meditar seriamente en ello, contestar al Sr. Ministro rehusando dicha Dignidad. No tengo palabras suficientes, Excmo. Sr., para manifestar mi reconocimiento por la benevolencia con que caba de distinguirme la cual me obliga á amar mas y mas á la Santa Sede, de quien es V. E. dignísimo representante». La correspondencia sobre su elección como obispo se encuen-
} 
También afirma que se le pide un acto heroico para el que no tiene fuerzas, a la vez que pide perdón por no haber complacido las intenciones de su obispo. Asevera: «no ha sido por falta de cariño, que lo tengo grandísimo, sino porque charitas bene ordinata incipit a semetipso». E incluso dice más en la posdata de esta carta, donde asoma su carácter personal: «matarme en un rincón antes que aceptar tal cosa. Estoy pasando horrores, y como sé lo que soy no puedo tomar tal carga. Digaselo al Sr. Nuncio. Harto siento dar este disgusto, pero es preferible á otros que serían tardes y mas graves» ${ }^{11}$.

Por su parte, el obispo de Segovia se dirige al nuncio apostólico de Madrid contándole como se acercó personalmente hasta la casa de los PP. Misioneros con el objeto de convencer a su arcipreste para que aceptara el obispado ofertado, no pudiendo conseguirlo. En esta carta también muestra su disgusto por la obstinación del electo al afirmar una y otra vez que él no sirve para obispo. Finalmente, añade una minuta escrita por don Eustaquio en la que deja constancia de las razones para no aceptar la sede canaria: el peligro de una afección que padece a la vista desde hace doce años, la poca memoria especialmente para retener nombres propios, el escaso espíritu de abnegación y la gravísima responsabilidad que tal cargo supone ante Dios, la Iglesia y la sociedad. Otras razones más son: la dificultad para comunicarse con personas de toda confianza en casos urgentes, la situación especial de las islas bajo el aspecto político-nacional, y la distancia de seis días de viaje desde su país ${ }^{12}$.

\subsection{La renuncia de mons. Cueto}

Después de renunciar al obispado de Canarias, se vio obligado a aceptar el obispado de Ourense, tras el fallecimiento de mons. Carrascosa y Gabaldón (18951904) en Xunqueira de Ambía el 15 de mayo de $1904^{13}$. A esto también contribuyó que el piadoso obispo de Canarias, el dominico José Cueto Díez de la Maza, declinara su traslado a nuestra diócesis tras propuesta del Ministerio de Gracia y Justicia ${ }^{14}$. Entre los informes enviados a nunciatura hay uno de 26 de mayo de 1904 en que se hace una comparación sobre qué diócesis, Astorga u Ourense, sería más propicia para el prelado insular. Dice al respecto:

\footnotetext{
tra bajo el siguiente título: Provvista di Sedi Vacanti: provvista della sede di Orense vacante per morti di Mgr. Carrascosa y Gabaldon (maggio 1904).

${ }^{11}$ Carta del presbítero Ilundain al obispo de Segovia, en ibíd., ff. 251r-252r.

${ }^{12}$ Apéndice de la carta del obispo de Segovia al nuncio apostólico. Segovia, 23 de junio de 1904, en ibíd., f. 257r.

${ }^{13}$ Obiit Paschalis Carrascosa y Gabaldón, en ASV, Arch. Nunz. Madrid, busta 660, fasc. 3, ff. 94-95.

${ }^{14}$ Santiago Cazorla LeÓn - Julio SÁnchez Rodríguez, Obispos de Canarias y Rubicón, Madrid: EYPASA, 1997, pp. 423-428.
} 
«el dialecto gallego no es obstáculo, pues el pueblo entiende el castellano, y en castellano se expiden los documentos oficiales tanto de la administración eclesiástica como civil, y en la Capital y pueblos importantes, al menos, se hace la predicación en castellano. Ni tampoco creo que obispo alguno de la región gallega predique o haya predicado en gallego ni que la circunstancia de hablar ese dialecto haya sido considerada como importante para la designación de Prelados en el territorio de Galicia. No tengo datos bastantes para comparar las dificultades de gobierno de las Diócesis de Orense y Astorga, pero me inclino a creer que el pueblo de Orense es más sencillo y dócil, y por tanto más fácil de gobernar que el de Astorga» ${ }^{15}$.

Otras posibles combinaciones que se manejaron con relación al obispo de Canarias fueron aquélla de Badajoz, diócesis que lo hubiera acogido de buena gana ${ }^{16}$, así como la de Salamanca, destino aconsejado por el cardenal Casañas, obispo de Barcelona. Anota el nuncio en la parte superior de la carta de este último: «Confidencial. R. il 12 che quando riceve questa lettera a Madrid già inviato a Roma la combinazione di nomine proposte del Governo in cui il Vescovo di Canarias figura per Orense» ${ }^{17}$.

Ahora bien, Fr. José continúa cada vez más firme en su propósito de no cambiar de diócesis, aduciendo como principal dificultad su edad de 65 años. Por otra parte, indica que «aquí me ha hecho el Señor la gracia de ser generalmente apreciado durante los trece años que van á cumplirse de mi pontificado, habiendo manifestado muchos de estos fieles que me quieren conservar entre ellos, y que parece hasta ingratitud dejarlos por otros ${ }^{18}$. Estando así las cosas, al día siguiente, el cardenal Merry del Val emite un telegrama a las once de la mañana para que se suspenda todo acto y comunicación en relación con la referida tentativa de preconizarlo para la diócesis auriense. Un día después, con la reseña de «confidentialle», se lo hará saber el auditor de nunciatura al ministro de Gracia y Justicia:

\footnotetext{
${ }^{15}$ Carta del P. Bernardino al nuncio apostólico de Madrid, en ASV, Arch. Nunz. Madrid, busta 659, tit. VII, rub. II, sez. I, n. ${ }^{\circ} 20$, ff. 267r-268r.

${ }^{16}$ Carta del P. José Díaz, O. P., secretario de estudios del seminario, al nuncio apostólico de Madrid. Badajoz, 4 de mayo de 1904, en ibíd., f. 271r: «el ultimo de los fieles de la Iglesia, y el menor de los hijos de Santo Domingo, compañero y confidentes del Sr. Hevia -obispo anterior- suplico á V. E. que se apiade de esta Diócesis y envíe algún Obispo que siga el mismo espíritu para salvar las almas que tienen hambre de doctrina cristiana y deseos de ver moral práctica; y me atrevo á suplicar al representante de la Santa Sede en esta nación española que tenga piezas de esta posición del rebaño de Pedro que no tienen pasto ni pastores, y le pido ponga los ojos en el Ilmo. Sr. Cueto, grande amigo del difunto, y por sus condiciones personales, muy apto para seguir el impulso dado».

${ }^{17}$ Carta del cardenal Casañas al nuncio apostólico de Madrid. Barcelona, 6 de junio de 1904, en ibíd., f. 272r.

${ }^{18}$ Carta de Fr. José, obispo de Canarias al nuncio apostólico de Madrid. Las Palmas, 23 de junio de 1904, en ibíd., ff. 275r-276r.
} 
«Je reçois à l'instant un télégramme del'Emmo. Card. Secrét. d'Etat, dont je ne cómprese à Vous faire connaitre l'objet de Son Em. ne informe d'avoir apprès qu' à la S. C. des EE. et RR. est pendante une grave affaire concernant l'Evêque de Canarias et comme lui ne peut s'agir de le transferer à autre Diocèse jusqu'à ce que la question ne soit resolue. Elle m'ordonne de suspendre tout acte et communication rélatifs à la translation du dit Prélat à Orense. Pour ce motif reste en suspens la nomination d'un nouvel Evêque pour Las Canarias. Mgr. de Segovia me a écrit hier qu'il n'a pas réussir à convaïncre l' archiprêtre de son Chapitre à accepter la Siège Episcopal de Las Palmas (Canarias) parce que celui est persuadé de n'avoir pas les qualités requisés. J'attendrai de connaître ses intentions, avant de faire s'il y aura lieu, des insistences du même candidat» 19 .

\subsection{Propuesta para Ourense}

El proceso que vincula esta diócesis gallega con don Eustaquio comienza con la carta que suscribe el canónigo papal de esta Iglesia Catedral, don Francisco Álvarez Novoa, quien, nombrado por el finado pontífice León XIII, se toma la libertad de manifestar que la mayor y más sana parte de los fieles de la diócesis auriense ha visto con disgusto que todas las vacantes de obispados hayan sido proveídas de pastores, menos la de Ourense, acaso la más necesitada, a juicio de esta dignidad. Apunta que desde la muerte de mons. Carrascosa, «se ha constituido aquí un estado de cosas tan excepcional que, exige y reclama con prontitud un obispo digno, celoso y enérgico que venga á gobernarla» ${ }^{20}$.

No entra en los detalles que motivan esta urgencia, pues para ello precisa que tendría que hacer relación de hechos que no cree prudente confiar al correo y que de permitírselo las circunstancias se lo explicaría verbalmente al nuncio. Es tanta la urgencia que llega a afirmar que sería una gran desgracia para la diócesis que en el próximo consistorio no fuera preconizado el obispo de Ourense. Tal vez, se refiera al expediente abierto por la diócesis auriense a los herederos del obispo finado, mons. Carrascosa, a fin de que se distinga el patrimonio personal de aquel diocesano, problemática que solucionará con acierto su sucesor ${ }^{21}$.

Tal reclamo encuentra respuesta en el ministro de Gracia y Justicia quien remitiendo correspondencia a don Arístides Rinaldini, nuncio apostólico de Madrid,

${ }^{19}$ Carta del auditor de nunciatura al ministro de Gracia y Justicia. Madrid, 25 de junio de 1904, en ibíd., f. 274r.

${ }^{20}$ Carta del canónigo Francisco Álvarez Novoa al nuncio apostólico de Madrid. Orense, 18 de julio de 1904, en ibíd., f. 258.

${ }^{21}$ Consultazione del Vescovo di Orense sopra la amanazione e tenore di un suo Decreto. Orense, 7 de abril de 1909, en ASV, Arch. Nunz. Madrid, busta 703, tit. VII, rub. II, sez. III, fasc. 4, n. ${ }^{\circ}$ 53, ff. 94r-96r 
aboga la propuesta del arcipreste de Segovia don Eustaquio Ilundain por la facilidad que supondría la elaboración de su proceso al haber sido incoado para la anterior combinación en la que no quiso aceptar mitra, pero que esperaba que aceptaría la de Ourense por la conveniencia de su rápida provisión así como por la proximidad geográfica de esta diócesis en relación con la suya natural ${ }^{22}$.

Tras regresar mons. Rinaldini a nunciatura el 4 de agosto después de una ausencia de varios días, y enterándose del contenido de la carta anterior del 23 de julio, así como de la aquiescencia mostrada por el Rey y el Gobierno con esta providencia a 4 de agosto, remite con inmediatez por telégrafo a la Santa Sede la propuesta del arcipreste de Segovia para la sede vacante de Ourense en estos términos: «Cardinale Segretario Stato. Roma. / Situazione in Orense richiedendo affrettare nomina Vescovo, Governo propone degno Arciprete Segovia che era accettato per Canarias. / Nuncio / Madrid 5 agosto 1904» ${ }^{23}$.

Sólo dos días después, el cardenal Merry del Val expide un telegrama con remite de nunciatura de Madrid en que manifiesta la conformidad del Santo Padre con aquella propuesta para que comiencen los trámites relativos ${ }^{24}$. Finalmente, aceptará el obispado de Ourense, tal como se lo comunica mons. Rinaldini a don Joaquín Sánchez de Toca, al mismo tiempo que urge su tramitación en el Ministerio de Gracia y Justicia ${ }^{25}$. Al nuncio apostólico de Madrid le costó lo suyo convencer al arcipreste de Segovia, cosa que sólo consiguió al exponerle que tal proposición era voluntad del Papa Pío X.

\subsection{Proceso consistorial y entrada}

En la positio que recoge el proceso elaborado en la Sagrada Congregación Consistorial, dicasterio encargado de dotar a la sede de Ourense de un nuevo pastor, se exponen las características de la diócesis vacante y las cualidades personales del candidato presentado por el monarca español Alfonso XIII. Unido al proceso canónico compilado en la nunciatura apostólica de Madrid, aparece el decreto consistorial del 22 de septiembre de 1904, paso previo que ultima la preparación ulterior de los actos relativos a la preconización del citado sujeto, que deberá tener lugar en el

\footnotetext{
${ }^{22}$ Carta del ministro de Gracia y Justicia al nuncio apostólico de Madrid. Madrid, 23 de julio de 1904, en ASV, Arch. Nunz. Madrid, busta 659, tit. VII, rub. II, sez. I, n. ${ }^{\circ} 20$, f. 260r.

${ }^{23}$ Carta del nuncio apostólico de Madrid al ministro de Gracia y Justicia. Madrid, 5 de agosto de 1904, en ibíd., ff. 262r-263r, y telegrama, en ibíd., f. 264r.

${ }^{24}$ Telegrama del secretario de Estado al nuncio apostólico de Madrid. Roma, 7 de agosto de 1904, en ASV, Segr. Stato, 1904, 249, fasc. 1, f. 148r.

${ }^{25}$ Carta del nuncio apostólico de Madrid al ministro de Gracia y Justicia. Madrid, 13 de agosto de 1904, en ASV, Arch. Nunz. Madrid, busta 659, tit. VII, rub. II, sez. I, n. ${ }^{\circ} 20$, f. 281 r.
} 
próximo consistorio. La documentación referida es enviada por el Sustituto del Consistorio Scipio Tecchi al Secretario de la Congregación Consistorial Giulio Grazioli ${ }^{26}$.

Auria, ciudad y cabeza de provincia del mismo nombre en el reino de Galicia, aparece edificada a orillas del río Miño, contando con más de cinco mil habitantes. La iglesia catedral de sólida estructura gótica, tiene como patrón titular a San Martín de Tours. Esta diócesis, sufragánea de Santiago de Compostela, consta de cabildo compuesto por cinco dignidades, a saber: deán, arcipreste, archidiácono, lectoral y maestrescuela. Además están el penitenciario y el doctoral, junto con una docena de capellanes beneficiados. En la catedral no hay pila bautismal, al dejar de ser parroquia. Pero, sí los oficios divinos propios, varios relicarios, órgano, campanario con campanas y cementerio extra urbe. El palacio episcopal, bastante amplio y decente, se encuentra muy próximo a la catedral. La mesa episcopal está tasada según los libros de Cámara en 1400 florines ${ }^{27}$.

La superficie de la diócesis consta de casi 6000 kilómetros y el número de habitantes asciende hasta 360.000 , casi todos católicos. Los sacerdotes diocesanos son 860 y los seminaristas 147 . La diócesis se compone de 593 parroquias y 87 iglesias anejas a una matriz, con 761 templos entre iglesias y capillas, siendo el número de feligreses de las principales de 4000 a 5000 habitantes, y de las más pequeñas de 200 a 300. Hay 37 arciprestazgos, además de numerosas casas religiosas tanto masculinas como femeninas. A grandes rasgos, éste es el estado de la diócesis auriense que se refleja en la positio consistorial y en la relación ad limina de $1917^{28}$.

A esta silla episcopal es promovido don Eustaquio, de cuarenta y dos años de edad, de quien se hace una breve relación de méritos, en su mayoría ya aludidos más arriba. El Sustituto del Consistorio, Scipio Tecchi, indica, por ejemplo, que «in functionibus obeundis ecclesiasticis sese laudabiliter exercuit. In suae diocesis Seminario primum Professor electus est ac deinde in Cathedrali Ecclesia Cluniensi canonicatum theologalem obtinuit: ac demum Segobiae Rector Seminarii atque Canonicus Archipresbyter Ecclesiae Cathedralis huiusque est renunciatus. Vir doctrina, gravitate, prudentia, morum honestate rerumque usu praeditus; dignus propter censendus qui memoratae Auriensis Ecclesiae in Episcopum praeficiatur». Concluido el proceso consistorial, renuncia a su posición de arcipreste de la catedral castellana y hace profesión de fe ante mons. Cadena y Eleta, obispo de Segovia,

\footnotetext{
${ }^{26}$ ASV, Uditore S. S., pos. 14 nov. 1904.

${ }^{27}$ Ibíd., pos. 14 nov. 1904.

28 José Ramón HeRnÁNDEZ FigueIREdo, Un documento inédito vaticano: relatio de statu Ecclesiae et Diocesis Auriensis Sacrae Congregationi consistoriali anno 1917 exhibita, en «Auriensia» 7 (2004), pp. 323-371.
} 
tarea delegada por el nuncio apostólico de Madrid y arzobispo de Heraclea, don Arístides Rinaldini ${ }^{29}$.

Preconizado el 14 de noviembre de 1904, fue consagrado en Pamplona el 13 de marzo del año siguiente, en la Capilla de Nuestra Señora del Camino. Los prelados asistentes eran Fr. José López Mendoza, obispo de Pamplona y don José Salvador y Barrera, obispo de Tarazona, mientras que el consagrante es su promotor don José Cadena y Eleta, obispo que fue de Segovia y a la sazón lo era de la diócesis de Vitoria $^{30}$. Tomó por lema de su escudo Omnia honeste et secundum ordinem fiant, que retrata su carácter y estilo pastoral. Dice así el breve que lo nombra para la silla episcopal auriense:

«Ex officio supremi Apostolatus quo nullis quiden meritis Nro. in sublimi Principis Apostolorum Cathedra collocati pringimur, Cathedrali Ecclesiae Auriensi, cui bonae memoriae Paschalis Carrascosa et Gabaldon, ultimus eius Antistes praesidebat, per eiusdem Paschalis obitum, extra Romanam Curiam defuncti, pastoris solatio destitutae de persona dilecti filii Eustachii Ylundain et Esteban presbyteri Dioecesis Pampilonensis Doctoris fidem et professi, omniaque et habentis, quem Carissimus in Xto. Filius Noster Alphonsus XIII Hispaniam Rex Catholicus Nobis ad hoc per suas litteras praesentavit, Nobis et PP. RR. Cardd. ob meritorem eius praestantiam accepta, de fratrum eorumdem consilio apostolica auctoritate nostra provvidemus eumdemque dilectum filium Eustachium dictae Ecclesiae Auriensi in Episcopum praefecimus et Pastorem curam committendo, reservata Nobis et Apostolicae Sedi novam ineundi istius Dioecesis circumscriptionem, quovis tempore nostro et eiusdem S. Sedis arbitrio peragendam. Voluimus autem et apostolica auctoritate decrevimus, ut Archipresbyteratus quo dictus Eustachius in Episcopum, ut supra electus, in Cathedrali Ecclesia Segobiensi potitur, per huiusmodi provisionem vacet ei ipso, suspenso tamen vacationis effectu usque ad praedictae Suae Sedis Auriensis possessionem. Non obstantibus apostolicis nec non dictae Ecclesiae Auriensis etiam iuramentos quibus cumque absolventes eumdem dilectum filium Eustachium a censuris ad effectus. Datum S. P. die 14 Novembris $1904 »^{31}$.

${ }^{29}$ ASV, Uditore S. S., pos. 14 nov. 1904.

${ }^{30}$ Lamberto de ECHEVERRía, Episcopologio Español Contemporáneo (1868-1985). Datos biográficos y genealogía espiritual de los 585 Obispos nacidos o consagrados en España entre el 1 de enero de 1868 y el 31 de diciembre de 1985, Salamanca: Universidad de Salamanca, 1986, p. 67, n. 153; Vicente CÁrCEl OrTí, Nombramientos de obispos en España durante el pontificado de San Pío X, en «Analecta Sacra Tarraconensia» 68 (1995), p. 249; Annuaire 1920, p. 271; DHEE II (1973), pp. 11891190; Zeno PIETA, Hierarchia Catholica, IX (2002), p. 74.

${ }^{31}$ ASV, Secreteria dei Brevi, 6217, ff. 167r-171r, en cuya parte interna lleva inserta la siguiente minuta: «Romae / In Palatio Aplco. Vaticano / Feria II Die XIV Mensis Novembris MDCCCCIV / SSmus. Dnus. Nr. / Ad praesentationem Serenissimi Regis Catholici providit Cathedrali Ecclesiae Aurien vacan per obitum bonae memoriae Paschalis Carrascosa et Gabaldon ultimi illius Episcopi extra romanam curiam defuncti de persona R. D. Eustachii Ylundain et Esteban, presbyteri dioecesis 
Hizo su entrada el 2 de abril, permaneciendo en la capital gallega por espacio de quince años. Le acompañaban don Natalio Sarasa y Oteiza y don Demetrio Ripalda y Gelo, quienes ocuparían los cargos de vicario general y secretario de Cámara del Obispado, respectivamente. El vicario capitular, don Tomás Sousa Castiñeiras ${ }^{32}$, sería el encargado de presentar las autoridades y comisiones al nuevo obispo, a quien hizo subir a un landó descubierto para entrar en la ciudad desde la estación de As Caldas, donde había llegado a las cinco de la tarde el tren procedente de Monforte. Le acompañaban el alcalde de la población, y los gobernadores civil y militar. La entrada fue solemne, no faltando las manifestaciones externas de júbilo y adorno, así como la velada del seminario ${ }^{33}$. Fiel reflejo de este regocijo es la carta por la que mons. Ilundain y Esteban hace saber al nuncio apostólico en España y al secretario de Estado sobre el éxito de su entrada en estos términos: «hice el pasado domingo mi entrada solemne en Orense, recibiéndome el clero y pueblo, gracias á Dios, con el mayor respeto y entusiasmo. Ayer puse mi despacho para el Sr. Srio. de Estado de S. S. el Papa anunciándole esto mismo» ${ }^{34}$.

\section{PREOCUPACIÓN Y CUIDADO DEL CLERO}

Desde el primer momento, mons. Ilundain se entregó a su grey, siendo su actividad pastoral intensa. El boletín del obispado publicaba el mismo día de su entrada en la diócesis su primera carta pastoral, y al poco tiempo comenzaba la visita pastoral. Era joven don Eustaquio, y sólo así se hace creíble, si se tienen en cuenta los medios de movilización que entonces había, el que en cinco años visitase las casi seiscientas parroquias que componían la diócesis auriense en aquel momento ${ }^{35}$. Después de su primera visita pastoral, mons. Ilundain conocía su grey, se sentía padre de sus fieles, en especial de sus sacerdotes, por lo que acomete las primeras reformas que encontraban en el sínodo el cauce idóneo. Dedicará una atención

\footnotetext{
Pampilonensis, doctoris fidem professi, omniaque habens ipsumque illi Auriensi ecclesiae in Episcopum praefecit et pastorem curam commitendo, cum reservatione novae circumscriptionis ipsius dioecesis; cum decreto vacationis Archipresbyteratus quo in Ecclesia Cathedrali Segobiensi potitur supreme tamen vacationis effectu usque ad Suae Sedis possessionem absolvens cum clausulis. / Vicecancelarius».

${ }^{32}$ ACOu, Actas Capitulares, 28 de mayo de 1904.

${ }^{33}$ BODO LXXIII, 1627 (10 abril 1905), pp. 115-121.

${ }^{34}$ Carta del obispo de Ourense al nuncio apostólico. Orense, 4 de abril de 1905, en ASV, Arch. Nunz. Madrid, busta 659, tit. VII, rub. II, sez. I, n. ${ }^{\circ} 20$, f. 279 r.

35 BODO LXXVIII, 1760 (8 octubre 1910), pp. 302-303.
} 
especial al Seminario ${ }^{36}$ y al clero, llegando a realizar tres visitas pastorales a toda la diócesis y la visita ad limina también por tres veces ${ }^{37}$.

\subsection{Convocatoria y desarrollo del Sínodo diocesano}

Hombre de iniciativa y tenacidad, quiere ser padre para todos. Al mismo tiempo es gobernante, y se descubre como pastor entregado y autoritario. Por otra parte, se muestra atento a las directrices de Roma, con lo que el sínodo diocesano de Ourense de 1908 responde al sentido universal de eclesialidad que el prelado convocante vive. Su pretensión es aplicar en la diócesis lo que el Concilio Provincial Compostelano de 1887, ya veinte años antes, había ordenado, y así ponerlo en práctica más plenamente ${ }^{38}$. Además las constituciones que estaban en vigor eran del sínodo de 1619, celebrado por don Pedro Ruiz de Valdivieso, resultando inaplicables por la transformación dada en la disciplina eclesiástica a raíz de los cambios acaecidos a lo largo de la convulsa centuria decimonónica, y por la influencia notoria de los errores del modernismo ${ }^{39}$. Su contenido y estructura interna es muy similar a los de otros sínodos celebrados en esa época ${ }^{40}$.

El 28 de marzo de 1908, el cardenal prefecto de la Sagrada Congregación del Concilio firma el rescripto de autorización de un sínodo en la diócesis de Ourense ${ }^{41}$. Los responsables de la elaboración de su proyecto de constituciones fueron varios capitulares, arciprestes y eclesiásticos, todos ellos cualificados. El cabildo, en

\footnotetext{
${ }^{36}$ Cfr. José Ramón Hernández Figueiredo, El Seminario Conciliar de San Fernando. Historia de una institución de piedad y cultura, Ourense: Diputación Provincial, 2004, pp. 389-424; ID., Planteamientos pedagógicos del Seminario Conciliar de San Fernando de Ourense (1804-1952). El reglamento como cauce de formación, en «Hispania Sacra» LVI, 114 (2004), pp. 637-659.

${ }^{37}$ ASV, Congr. Concist., Relat. Dioec., Aurien, busta 90, fascicoli inseriti. Sólo se guardan dos de las tres que realizó con los siguientes títulos: Relatio status Ecclesiae et Dioecesis Auriensis pro quadriennio octogesimo primo. Auriae die 21 Octobris anni 1909, fols. 2r, 4r-17v. Y, la Relatio de Statu Ecclesiae et Diocesis Auriensis Sacrae Congregationi Consistoriali anno 1917 exhibita, fols. 2r-37r. Falta la segunda, de 1913, que coincidiría con la peregrinación del jubileo constantiniano.

${ }^{38}$ M. Ríos, Santiago de Compostela, Diócesis de, en DHEE IV (1975), pp. 2192-2202.

${ }^{39}$ Constituciones sinodales del obispado de Orense, compiladas hechas y publicadas por S. S. Ilma. Dn. Pedro Ruiz de Valdivieso, por la Viuda de Andres Agustín Balboa, Madrid 1622. Reimpresas por Dn. Juan Manuel Bedoya, Gobernador de la Sede Vacante de Orense, Orense: Imprenta de Don Juan María de Pazos, 1843.

${ }^{40}$ Cfr. Camilo Salgado Vázquez, Los clérigos en el Sínodo Diocesano de Ourense de 1908, Tesina inédita, Salamanca: Universidad Pontificia de Salamanca, 2002, pp. 71-175, trabajo que sigo de cerca para la exposición de este apartado.

${ }^{41}$ Se publicaron en un tomo: Constituciones Sinodales promulgadas por el Excmo. e Ilmo. Señor Dr. D. Eustaquio Ilundain y Esteban, obispo de Orense, senador del Reino, etc. etc. En el Sínodo Diocesano celebrado en la Santa Iglesia Catedral de Orense los días 14, 15 y 16 de junio de 1908, Orense: Imprenta de A. Otero, 1908, p. 205.
} 
sesión extraordinaria celebrada el 4 de mayo de 1908, prestó su voto y conformidad para que las constituciones sinodales pudieran ser promulgadas, así como su felicitación por haber dado cima a un trabajo tan arduo y difícil, formando un cuerpo de leyes que vienen a llenar una de las primeras necesidades que se sentían en la diócesis $^{42}$. Finalmente, mons. Ilundain y Esteban, en virtud de su autoridad ordinaria, convoca sínodo diocesano para los días 14, 15 y 16 de junio de 1908.

Fueron en total trescientos sesenta y ocho los asistentes y participantes en el Sínodo Diocesano. El conjunto estaba distribuido de esta forma: el obispo convocante, don Eustaquio Ilundain; el provisor y vicario general, don Natalio Sarasa; la totalidad del clero de la catedral, que sumaban treinta y tres; nueve del clero del seminario; todo el clero de la ciudad que sumaban veinte; doscientos noventa y ocho del clero de los arciprestazgos; y seis representantes de los institutos religiosos masculinos ${ }^{43}$.

¿Cómo se desarrolla el sínodo? Lo que en él se hace sencillamente es proclamar las constituciones, que fueron previamente preparadas, leyéndolas en la asamblea sinodal reunida. Así se explica que en tres días se pueda desarrollar un evento eclesial tan importante y de máxima relevancia para el devenir de toda la diócesis. La trascendencia de lo que en el sínodo se hace es muy grande porque en él se dan las bases de todo un nuevo modo de actuar y regirse la diócesis, y de ahí la razón de que se convoque a tan gran número de clérigos para este acto. Se puede decir que lo que se hace en los tres días, que dura el sínodo, es como la entrega solemne de las nuevas Constituciones Sinodales y la celebración litúrgica de este hecho. El obispo, sólo él, es el que promulga las constituciones sinodales ${ }^{44}$.

El sínodo auriense contiene trescientas cincuenta y tres constituciones, distribuidas en ocho títulos que a su vez están divididos en capítulos. Esta división corresponde con aquélla del Concilio Provincial Compostelano de $1887^{45}$ y que el sínodo de Santiago de 1891 también asume, aunque éste último añade un título más, que lleva el nombre de «las penas», con el número nueve. He aquí los títulos: I. De la fe católica; II. De los santos sacramentos; III. Del culto; IV. De la vida y honestidad de los clérigos; V. De las personas eclesiástica; VI. De los bienes de la Iglesia; VII. De la curia eclesiástica diocesana; VIII. Del pueblo cristiano ${ }^{46}$.

\footnotetext{
42 Ibíd., p. VIII.

${ }^{43}$ Ibíd., pp. 342-356. En el apéndice XXIX a las Sinodales aparecen los nombres de todos y cada uno de los participantes en el Sínodo y a título de qué su participación.

${ }^{44}$ Camilo Salgado VázQuez, Los clérigos en el Sínodo Diocesano de Ourense de 1908, o.c., pp. 74-76, donde detalla los pormenores de su celebración.

${ }^{45}$ Acta et decreta concilii provincialis compostellani 1887, Compostellae 1890, pp. V-VIII.

${ }^{46}$ Camilo Salgado VázQuez, Los clérigos en el Sínodo Diocesano de Ourense de 1908, o.c., pp. 77-80.
} 
El obispo auriense informa puntualmente de la convocatoria y desarrollo del sínodo al nuncio apostólico de Madrid ${ }^{47}$, así como de su desenlace. Al término de este evento eclesial singular, mons. Ilundain plasma en las siguientes palabras su sentir:

Mi venerado Sr. Nuncio: Es grandísima la satisfacción que siento en comunicar á V. E. que ayer terminaron con toda felicidad las sesiones del Sínodo Diocesano que se inauguró el día 14 en esta Ciudad. / Ha asistido á él la mitad del Clero de la Diócesis, al tenor del edicto de indicción, 368 sacerdotes. / Las Constituciones Sinodales promulgadas fueron recibidas, gracias á Dios, muy bien, haciendo todo augurar que la bendición Apostólica que nos envió el Padre Santo al terminar el Sínodo será augurio de feliz éxito y provechosos resultados. / Me apresuro á comunicar á V. E. estas noticias, expresando al mismo tiempo que mi Clero ha elevado á Su Santidad sentido homenaje de acatamiento y sumisión ${ }^{48}$.

El sínodo de Ourense de 1908, pese a que en 1917 se publicó el Código de Derecho Canónico, fue instrumento legal que sirvió para la marcha de la diócesis y se mantuvo en esta función largo tiempo. Fue medio de exigencia concreta y extensiva a todos, garantía de seguridad y pauta de referencia. Marcó un antes y un después en la vida diocesana, sin que supusiera una ruptura. Acogido con interés, las constituciones promulgadas han estado vigentes hasta el Concilio Vaticano II.

\subsection{Sobre el clero en el Sínodo}

Ciertamente la figura del sacerdote es central en la vida de la Iglesia viva, real y encarnada en las comunidades parroquiales. Por eso, analizando el sínodo desde esta vertiente, se atisba una reducida, pero auténtica imagen de la iglesia diocesana, en este caso ourensana, que vivía a comienzos del siglo XX. Como bien expone el licenciado Camilo Salgado, el sínodo diocesano de 1908 refiere parte de sus constituciones a los candidatos al sacerdocio, vida y honestidad de los clérigos, y actividad pastoral de los mismos en su triple función de enseñar, santificar y gobernar. Este código legislativo está enraizado a su vez en la rica tradición de la Iglesia siendo prueba de la comunión de fe y vida que en ella es esencial ${ }^{49}$.

${ }^{47}$ Carta del obispo auriense al nuncio apostólico de Madrid. Orense, 12 de mayo de 1908, en ASV, Arch. Nunz. Madrid, busta 707, tit. IX, sez. I, n. ${ }^{\circ}$ 2, f. 10r.

${ }^{48}$ Carta del obispo auriense al nuncio apostólico de Madrid. Orense, 17 de junio de 1908, en ibíd., f. 11r.

49 Camilo Salgado Vázquez, Los clérigos en el Sínodo Diocesano de Ourense de 1908, o.c., p. 81. 
Sobre los candidatos al sacerdocio ${ }^{50}$ haremos una exposición aparte al referirnos al funcionamiento del Seminario Conciliar en un epígrafe propio. En cuanto a la vida de los clérigos, el sínodo asevera que el sacerdote es el dispensador de la gracia y auxilios de Dios a través del santo ministerio que desempeña, por lo que está llamado a ser luz del mundo, por el mensaje que anuncia, y sal de la tierra, por la integridad de su vida, viviendo en castidad, obediencia y desprendimiento. Insiste en los fundamentos de la vida sacerdotal, tanto en lo espiritual, que incluye la oración, la confesión, la misa y los ejercicios espirituales, como en lo humano, ya en la formación permanente, ya en el cuidado y presencia de su figura de pastor. Esta figura ha de estar garantizada por el uso del hábito clerical y por su propia vida, incluso privada, conformada en la moderación y la prudencia. La necesidad de este cuidado de la figura del sacerdote brota del influjo público especial que él tiene, tanto en la comunidad creyente como en la sociedad civil, y que está también protegido por la inmunidad eclesiástica con que se le rodea ${ }^{51}$.

He aquí algunos puntos: oración vocal, meditación y oficio divino, confesión y santa misa, hábito y tonsura, ejercicios espirituales, conferencias morales y litúrgicas, diversiones prohibidas a los clérigos, servicio doméstico, inmunidad eclesiástica y avisos saludables para la vida más personal de los clérigos. Sobre este último aspecto, el sínodo recomienda a los sacerdotes que aspiren a ordenar su vida según el modelo de vida del seminario, pero siempre subordinando eso a las necesidades de los fieles y gloria divina. El sacerdote ha de tener tiempo para orar, meditar, oír confesiones, celebrar misa, rezar el oficio divino, estudiar, despachar asuntos parroquiales, visitar a los enfermos, descansar, recrearse, y siempre buscando que sus días estén llenos de la presencia de Dios ${ }^{52}$.

La generosidad y la compasión con los pobres, en especial con los de la parroquia, han de distinguir al pastor, y los asilos y casas de caridad y misericordia han de contar en su preocupación. Si poseen algún beneficio procurarán, según los cánones, darle destino al sobrante ${ }^{53}$. También exhorta a que otorguen testamento en tiempo oportuno, determinando los sufragios que han de celebrarse por su alma y

50 Ibíd., pp. 82-88; Constituciones Sinodales promulgadas por el Excmo. e Ilmo. Señor Dr. D. Eustaquio Ilundain y Esteban, obispo de Orense, senador del Reino, etc. etc. En el Sínodo Diocesano celebrado en la Santa Iglesia Catedral de Orense los días 14, 15 y 16 de junio de 1908, o.c., pp. 49-52.

51 Camilo Salgado VÁzQuez, Los clérigos en el Sínodo Diocesano de Ourense de 1908, o.c., pp. 88-101; Constituciones Sinodales promulgadas por el Excmo. e Ilmo. Señor Dr. D. Eustaquio Ilundain y Esteban, obispo de Orense, senador del Reino, etc. etc. En el Sínodo Diocesano celebrado en la Santa Iglesia Catedral de Orense los días 14, 15 y 16 de junio de 1908, o.c., pp. 94-106.

${ }^{52}$ Ibíd., const. 176, p. 105.

${ }^{53}$ Ibíd., const. 177, p. 106. 
las limosnas a los pobres que bendigan su memoria, sin esperar a estar enfermos de gravedad. Que procuren no testar a favor de la sirvienta, dejar arregladas las cuentas de fábrica, las obligaciones de conciencia y el cumplimiento de misas. Finalmente dice que no echen en olvido el seminario diocesano, y pide que funden becas en beneficio del mismo ${ }^{54}$.

Por lo que se refiere a la labor docente, santificante y de gobierno de los sacerdotes, ésta es de máxima gravedad por lo que requiere un gran cuidado. Son las distintas caras de la única misión que los sacerdotes han de desempeñar: la evangelización ${ }^{55}$. El sacerdote ha de enseñar las verdades fundamentales de la fe, poniendo especial atención ante el modernismo, el racionalismo, el liberalismo y el socialismo, como fuentes de equívocos. Cuentan los sacerdotes con palestras especiales como son la predicación y la catequesis en esa tarea de enseñar, así como las escuelas ${ }^{56}$. Dentro de su intensa labor pastoral, mons. Ilundain impulsó la renovación catequética en conformidad con las orientaciones de Pío X en la encíclica Acerbo nimis, pudiendo apreciarse en la casi totalidad de las parroquias aurienses la fundación de las asociaciones denominadas de la Doctrina Cristiana ${ }^{57}$.

Por lo tanto, se puede concluir que el sínodo diocesano está dirigido especialmente al clero, que es el que ha de ponerlo en práctica instruyendo, cuidando, velando y santificando a la comunidad. En este sentido, se descubre una Iglesia sacramentalista y cultual, reivindicadora de sus derechos y con afán controlador de la sociedad. Se deduce que se corresponde con el tipo de clero de la época. Es el elemento configurador principal y determinante de la vida y marcha de la diócesis. Se percibe sentido de clase en el mismo, situándose por encima del pueblo o separado de él. Es como un cuerpo organizado y jerarquizado con escalafón y disciplina. Prima esta visión sobre el sentido de comunión y hermandad, aunque sin descuidar esta dimensión fraterna. Se cuida la formación permanente y todo está debidamente regulado para su vida y su misión pastoral. Entre las excelencias del sínodo hay que indicar el cuidado que para con el clero tienen sus cánones, tratando de que todos sus miembros estén bien formados y sobre todo que lleven una vida acorde con su ministerio. También resalto la organización que hay en los arciprestazgos

\footnotetext{
${ }^{54}$ Ibíd., const. 178, p. 106.

${ }_{55}$ Sobre la labor santificadora y de gobierno de los clérigos, cfr. Camilo SALGAdo VÁzQuEz, Los clérigos en el Sínodo Diocesano de Ourense de 1908, o.c., pp. 117-159; Constituciones Sinodales promulgadas por el Excmo. e Ilmo. Señor Dr. D. Eustaquio Ilundain y Esteban, obispo de Orense, senador del Reino, etc. etc. En el Sínodo Diocesano celebrado en la Santa Iglesia Catedral de Orense los días 14, 15 y 16 de junio de 1908, o.c., pp. 36-74, 82-201, respectivamente.

${ }^{56}$ Ibíd., pp. 101-117; ibíd., pp. 7-30 y ss.

${ }^{57}$ Pío X, Encíclica Acerbo nimis, 15 de abril de 1905, en BODO LXXIII, 1631 (9 junio 1905), pp. 151-179.
} 
exigiendo y facilitando que todo funcione según lo previsto, así como el cuidado del culto y el celo por sus fieles, que el sacerdote y pastor debe tener.

\subsection{Otras medidas}

Ante el descuido, y a veces abandono, de la vida espiritual del clero mons. Ilundain y Esteban establece, al poco tiempo de llegar, que haya dos o tres tandas de ejercicios espirituales para sacerdotes, y se hace público un calendario de fechas para los mismos ${ }^{58}$, anticipándose así a lo que luego el CIC de 1917 legisló. Asimismo en el campo moral se establece la celebración de conferencias morales mensualmente, en las que los sacerdotes se preparan mejor para su labor pastoral.

También la apariencia externa de los sacerdotes le preocupa y, en octubre del mismo año en que llega a Ourense, en una alocución pastoral al clero, en la que alude al Papa Pío V, al Concilio Tridentino y al Concilio Provincial Compostelano de 1887, ordena el uso del traje talar precisando exactamente como debe ser éste. Dice en su alocución pastoral que el Papa Martín V reprobaba el mal vestir del clero -«quodque mente gerunt habitu confitentur»- y como la asamblea tridentina en el c. 6 de la sesión XIV señala penas de suspensión - «ab ordine, officio et beneficio»y hasta la privación del beneficio, contra los que no visten el hábito clerical al tenor de los mandatos de su obispo, y que pueden ser impuestas ${ }^{59}$.

Repetidas veces en su ministerio instará a que se cumpla lo mandado, ordenando que los arciprestes velen por la disciplina. En este contexto, se entiende la consulta que dirige mons. Ilundain al nuncio apostólico y éste a su vez al cardenal secretario de estado sobre cómo se ha de proceder jurídicamente con el clero rural que no acostumbra a vestir hábito talar al menos desde hace tres siglos al concurrir a las ferias por otra parte tan frecuentes en Galicia, y negociar expeditamente en la compra y venta de bestias, incluso examinando los animales en venta tal como lo haría un veterinario. Y lo más grave es que algunos de estos sacerdotes no dudan en tomar parte de las funciones eclesiásticas con vestimenta secular ${ }^{60}$.

El prelado auriense quiere suprimir tales abusos, para lo que ve necesario el acudir a las censuras. En este sentido, no cree eficaz la censura ferendae sententiae, ya que en estas poblaciones es grande el respeto por el clero, no atreviéndose a descubrir tales excesos, por eso consulta si podría valerse de las censuras latae sen-

${ }^{58}$ BODO LXXIV, 1657 (7 julio 1906), p. 214. Los ejercicios tienen lugar en el mes de septiembre en el seminario.

${ }^{59}$ BODO LXXIII, 1639 (10 octubre 1905), pp. 295-298.

${ }^{60}$ Carta del nuncio apostólico de Madrid al Secretario de Estado. Madrid, 14 de mayo de 1908, en ASV, Arch. Nunz. Madrid, busta 707, tit. IX, sez. I, n. ${ }^{\circ}$ 2, f. 16 r. 
tentiae. Ante tal medida muestran connivencia algunos sacerdotes foráneos de la diócesis, mientras que los sacerdotes diocesanos la desaconsejan. Deseoso mons. Ilundain de proceder con pie seguro, envía esta consulta al nuncio de Su Santidad en España, de tal manera que si aplicara la referida censura, le gustaría estar seguro de que no habría de temer la invalidación de tal medida en un probable recurso a la Santa Sede ${ }^{61}$.

Secretaría de Estado remite una pronta respuesta al nuncio con el objeto de que la providencia que se adopte al respecto, se recoja en las constituciones que promulgue el sínodo a celebrarse en junio de 1908. Su eminencia Merry del Val consulta esta duda en la Sagrada Congregación del Concilio, dicasterio que dispone lo siguiente: «essere in facoltà del Vescovo il provvedere anche con censure latae sententiae o rimuovere quei gravi abusi; crederebbe però che tale censura debba essere limitata alla sospensione a divinis, e che debbano essere bene e chiaramente determinati i casi nei quali si incorrirebbe» ${ }^{62}$. Un mes más tarde, el nuncio se encargará de remitir esta respuesta a mons. Ilundain a raíz de su consulta con tiempo suficiente para que se plasme esta providencia en las auguradas constituciones sinodales ${ }^{63}$.

No pequeño problema es aquél de dotar las parroquias rurales a través de concurso, tal como era práctica corriente entonces. En este sentido se entiende el lamento reflejado en una carta que dirige un grupo de curas párrocos de la diócesis de Ourense al nuncio de Su Santidad en España. Tras la llegada de mons. Ilundain hacía ya cinco años, a los que había que sumar otros diez del pontificado de Carrascosa, en total ya eran quince los años durante los cuales no se había celebrado concurso en este obispado. Con tal motivo se hallaba vacante la mayor parte de la diócesis, resultando por tal circunstancia que los mejores curatos y de mayor categoría, se encontraban ocupados por jóvenes entrantes sin servicios anteriores, y por lo tanto sin experiencia y sin haber sido probados en concurso. Por el contrario, párrocos respetabilísimos y beneméritos por su virtud, ciencia y servicios, se hallaban encanecidos y sin esperanza de mayor fortuna, ocupando curatos de la más ínfima categoría, que le tocaron para prueba y mérito en su primera colocación de concurso general. Agregan en este oficio su sentir de agravio y desolación: «decimos sin esperanza de mejor fortuna, porque admitida una omisión tan anticanónica, que trae en continuo movimiento de una parte para otra a los Señores Ecónomos como si

\footnotetext{
${ }^{61}$ Ibíd., f. $16 \mathrm{v}$.

${ }^{62}$ Carta del secretario de estado al nuncio apostólico de Madrid. Vaticano, 25 de abril de 1908, en ibíd., f. 15 r.

${ }^{63}$ Carta del nuncio apostólico de Madrid al obispo de Orense. Madrid, 30 de mayo de 1908, en ibíd., f. 13r.
} 
fueran carabineros del reino, reputándose á cada paso los feligreses inciertos del $\mathrm{Sr}$. Cura que los rige ó del que los regirá en breve» ${ }^{64}$.

El sentir general es de un profundo descontento que engendra el odio y la más amarga censura en contra de su prelado. Los primeros, porque ven sin recompensa servicios tan penosos y sacrificios tan inevitables en ministerio tan delicado y en lugares que solo la cristiana y sacerdotal obediencia puede obligar a habitar, durante tiempo tan prolongado; descontentos también los segundos, pues, aunque algunos de estos ocupan los mejores economatos, se hallan como los demás expuestos a traslados inesperados «por no llamar caprichosos, y privados todos de una gran parte de la dotación como ecónomos, durante tan duradera situación, siendo ya ella tan exigua y mermada, aunque muy necesaria, atendidas las circunstancias sociales ${ }^{65}$.

Por último también se sienten descontentos los feligreses o parroquias, porque se ven privados a cada paso del cura con que se encontraban de algún modo identificados; y gobernados por su sucesor, que aunque animado del mejor espíritu, tiende sin pensarlo a modificar y alterar los planes del primero, ocasionando frecuentemente desaliento en los fieles, descontento y menos fruto, con proyectadas reformas y novedades, vacilando sobre qué plan ha de seguirse. A esto se agrega la desatención de las casas y huertos rectorales, lo mismo que la diligente atención de las iglesias y de los intereses de sus fábricas. Porque, no reputándose permanentes, los señores ecónomos procuran vivir al día, sin tomar medidas y resoluciones estables, entorpeciéndose toda la economía parroquial. Concluyen:

«Esto y mucho mas que esto pasa y sucede Excmo. Sr. con poca gloria de Dios, perjuicio de la iglesia y de las almas y desprecio del derecho que asiste á los Srs. Sacerdotes. / Por lo tanto, los que suscriben después de lo expuesto, suplican á V. E. Y. con la mayor reverencia y confianza, y esperando la mayor reserva, se digne interponer su autoridad y altísimo valimiento para obligar á este Excmo. é Yllmo. Prelado á la inmediata publicación del Concurso general para la pronta provisión de curatos en sus legítimos pastores, según santa y canónica obligación. Así confían en el celo de todos conocido de V. E. Y. / Si no puede tener efecto por alguna circunstancia, la precedente suplica; nos veremos obligados á elevar á las futuras Cortes y Gobierno de su magestad; y no siendo oidos en este elevado centro, expondremos por ultimo nuestra queja á la prensa, rebelándonos como ultimo recurso. / Este es el estado de cosas de este Obispado. Si V. E. Y. duda de nuestro aserto pida informes al clero del obispado, incluso al Yllmo. Cabildo, que exceptuados unos pocos favoritos por el Prelado, le dirán á V. E. toda la verdad. / En representación de sus compañeros: Andrés Doria, Juan Santillana, Julio Trabancos, Pedro Pelaez» ${ }^{66}$.

${ }^{64}$ Carta de un grupo de clérigos aurienses al nuncio apostólico de Madrid. Orense, 30 de abril de 1910, en ASV, Arch. Nunz. Madrid, busta 703, tit. VII, rub. II, sez. III, fasc. 4, n. ${ }^{\circ}$ 53, f. 85r.

${ }^{65} \mathrm{Ibíd}$., f. 85r-v.

${ }^{66} \mathrm{Ibíd}$., ff. 85r-v, 92r. 
En este contexto reivindicativo, se entiende la carta que dirige con mucho tacto el nuncio al prelado auriense pocos días después sobre el estado de las tratativas entre la diócesis y el gobierno para un arreglo definitivo de las parroquias, al mismo tiempo que le insta a que si éstas han concluido, le remita la fecha en que mons. Ilundain cree poder proclamar el concurso para la provisión de las parroquias conforme a las reglas del derecho vigente ${ }^{67}$. De tres días después, data la respuesta del prelado auriense en que informa de que el arreglo parroquial de esta diócesis fue definitivamente aprobado por Su Majestad en julio del año 1893. También expone que inmediatamente se planteó y algún tiempo después se celebró concurso general para la provisión de parroquias.

Por lo que se refiere a su pontificado, informa de la celebración de cuatro concursillos para provisión de parroquias de patronato laical, que son muchas en este obispado, y que el último año proyectó convocar concurso general de parroquias, pero que por las circunstancias especiales que el mismo nuncio tuvo la bondad de apreciar, demoró por algún tiempo la convocatoria. Lo mismo le aconsejó el secretario de estado, Merry del Val, cuando tuvo la ocasión de visitarle en noviembre del año pasado de 1909 con motivo de la visita ad limina y su exposición sobre el estado de la diócesis. Tal vez se refiera a los sucesos de Oseira. Ahora bien, una vez que han variado las circunstancias, espera celebrar dicho concurso general en el próximo otoño. Concluye que: «esto lo sabe el Clero, pues repetidas veces he manifestado á mis sacerdotes que aspiro á terminar la santa pastoral visita en el presente año, y sin más aplazamientos anunciar dicho concurso» ${ }^{68}$. Poco después, en verano de 1910, mons. Ilundain informará personalmente al nuncio de la celebración del concurso para la provisión de parroquias, remitiendo el adjunto edicto de convocatoria, el cual en breve se celebró para bien de esta diócesis ${ }^{69}$.

Celoso también se muestra mons. Ilundain de salvaguardar la integridad del depósito de la fe. De esta manera, se explica la satisfacción con que nuestro prelado pone en conocimiento del nuncio de Su Santidad en Madrid la noticia de que la totalidad del clero diocesano ha prestado el juramento prescrito en el Motu propio Sacrorum Antistitum, cuya obligación ha cumplido muy ex animo y abominando el modernismo ${ }^{70}$. El nuncio acoge el atento oficio del prelado auriense, al que res-

\footnotetext{
${ }^{67}$ Carta del nuncio apostólico al obispo de Orense. Madrid, 4 de mayo de 1910, en ibíd., f. 90r.

${ }^{68}$ Carta del obispo de Orense al nuncio apostólico de Madrid. Orense, 7 de mayo de 1910, en ibíd., ff. 89r y 91 r.

${ }^{69}$ Carta del obispo de Orense al nuncio apostólico de Madrid. Orense, 29 de julio de 1910, en ibíd., f. 86.

${ }^{70}$ Carta del obispo de Orense al nuncio apostólico de Madrid. Orense, 28 de febrero de 1911, en ibíd., f. 101r.
} 
ponde su intención de poner cuanto antes tan grata noticia en conocimiento de $\mathrm{Su}$ Santidad el Papa Pío X ${ }^{71}$.

Ese amor de pastor y padre no permite que nada quede para la improvisación y por eso, después de informarse bien sobre el tema, también pone en marcha la fundación de un montepío sacerdotal cuyo proyecto de reglamento se publica en 1906, siendo aprobado el 29 de enero de 1907. El obispo antecesor, don Pascual Carrascosa, había empezado un edificio para asilo de sacerdotes, pero don Eustaquio desistió de continuar con el proyecto después de informarse sobre el asunto y ver que el sentir general era de que los sacerdotes mayores preferían ser atendidos en sus propias casas ${ }^{72}$. De esta forma esa preocupación por cada sacerdote en su integridad, desde lo espiritual hasta lo material, se traducía en acciones concretas como respuestas acertadas que por supuesto requerían esa sintonía y colaboración de los mismos sacerdotes.

\section{EN LAS PARROQUIAS}

En el capítulo VII de la visita ad limina de 1917, entre los artículos 63 y 81, que llevan por título De parochiis, earumque rectoribus, mons. Ilundain presenta una síntesis bastante exacta del estado actual de las parroquias de la diócesis auriense. Según esta documentación, todas las parroquias tienen pastor propio, excepto cinco que son regidas por un párroco próximo, echándose en falta la presencia de vicarios parroquiales en algunas de ellas. La provisión de las parroquias se realiza por concurso según el método de Benedicto XIV, tal como se expone en su bula Cum illud. Por concurso general, el obispo Ilundain ha provisto de párroco más de trescientas. Dos de estas parroquias tienen como rector a un sacerdote regular. Corresponde a los examinadores sinodales el emitir un juicio sobre la piedad, la ciencia y las demás cualidades del candidato presentado a concurso. Don Eustaquio lamenta los incidentes acaecidos a causa de la difícil tarea de equiparar las tasas oficiales del obispado con derechos existentes desde antiguo en algunas parroquias. El beneficio respectivo de párrocos y coadjutores es tal como manda el Concordato de $1851^{73}$, además de los emolumentos y derechos de estola vigentes.

\footnotetext{
${ }^{71}$ Carta del nuncio apostólico de Madrid al obispo de Orense. Madrid, 4 de marzo de 1911, en ibíd., f. 101r.

72 Eustaquio Ilundain y Esteban, Proyecto de un Reglamento del Montepío Sacerdotal Orensano, en BODO LXXIV, 1667 (10 diciembre 1906), pp. 369-378.

${ }^{73}$ La edición bilingüe, en Raccolta dei Concordati su materie ecclesiastiche tra la Santa Sede e le autorità civili, I: 1098-1914, ed. Angelo MERCATI, Città del Vaticano: Tipografia Poliglotta Vatica-
} 
Casi todas las parroquias están dotadas de rectorales con diestros y huertas bastante amplios y fructíferos. Monseñor Ilundain y Esteban insiste en la obligación de cuidar diligentemente todos los libros parroquiales conforme a las leyes canónicas prescritas. Asimismo, exhorta a la aplicación de la misa pro populo, al ministerio de la predicación, a la instrucción catequética de los niños, a la administración constante del sacramento de la penitencia para la recepción frecuente de la eucaristía, a la preparación de los sacramentos del bautismo y el matrimonio, y a la atención continua de los enfermos. También han de ser atendidos convenientemente los distintos ejercicios de piedad como el rosario, el vía crucis en Cuaresma, el culto eucarístico, las novenas y el mes de junio en honor del Sagrado Corazón de Jesús. Por otra parte, como obras sociales dignas de reseña están los 17 sindicatos agrícolas que atienden diferentes consiliarios designados por el obispo ${ }^{74}$.

Fruto de su celo apostólico, fue la restauración con mejoras de alguna cuantía, de setenta iglesias parroquiales de la diócesis como la capilla mayor de la colegiata de Xunqueira de Ambía, así como la construcción de algunas iglesias como las de Mirallos, Louredo, Terroso Paradellas, Edrada, Refoxos, Barbantes, Dacón y muy particularmente la de Santiago de As Caldas, municipio hoy incorporado a Ourense ${ }^{75}$.

Injustamente la mayor parte de la documentación encontrada en los fondos vaticanos refieren episodios grises e incluso virulentos del pontificado de mons. Ilundain en su relación con las parroquias. Por esta razón, he querido exponer esquemáticamente en estos párrafos previos los logros pastorales de este obispo que son muchos, pero que no encuentran reflejo en la documentación de Nunciatura. De todos modos, parece ser que tales esfuerzos y sacrificios no pasaron desapercibidos ante la Santa Sede al promocionarle a la sede arzobispal hispalense, y que parte de los mismos se explican únicamente en el contexto de una política liberal, hostil y anticlerical.

na, 1954, pp. 771-795. La negociación del concordato debe seguirse a través de la correspondencia del nuncio Brunelli, en Vicente CÁRCEl OrTí, Los despachos de la Nunciatura de Madrid (1847-1857), en «Archivum Historiae Pontificiae» 13 (1975), pp. 311-400; 14 (1976), pp. 265-356. Los dos mejores estudios son de Federico SuÁrez, Génesis del Concordato de 1851, en «Ius Canonicum» 3 (1963), pp. 65-249; Juan PÉREZ Alhama, La Iglesia y el Estado español. Estudio histórico-jurídico a través del concordato de 1851, Madrid: Instituto de Estudios Políticos, 1967.

${ }^{74}$ Relatio de Statu Ecclesiae et Diocesis Auriensis Sacrae Congregationi Consistoriali anno 1917 exhibita, en ASV, Congr. Concist., Relat. Dioec., Aurien, busta 90, fascicoli inseriti, ff. 17v-22r.

75 BODO LXXXVII, 1970 (15 diciembre 1920), pp. 210ss.; Laureano TOVAR GonZÁLEZ, Ensayo biográfico del Emmo. Señor Cardenal Ilundain y Esteban, Obispo que fue de Orense y Arzobispo de Sevilla, o.c., pp. 123-124. 


\subsection{Los sucesos de Oseira}

\section{a) Contextualización}

Llevaba gobernando cuatro años la diócesis auriense el obispo Ilundain, y en tiempo tan breve su actividad fue tan intensa que, según el parecer de algunos contemporáneos, su pontificado habría de figurar como de los más fecundos del episcopologio ourensano. He aquí una ligera enumeración de sus actos: reformas materiales de mucho coste y de mayor conveniencia en el Seminario conciliar; reorganización de estudios y prudente disciplina en el régimen interior; saludables disposiciones para dignificación del sacerdote, esplendor del culto, fomento de la piedad y santificación del clero y pueblo, con misiones, ejercicios, conferencias, asociaciones y frecuencia de Sacramentos, santa visita pastoral de la diócesis, tan difícil de recorrer; preparación y promulgación de sinodales; instalación de escuelas cristianas en la casa episcopal de Xunqueira de Ambía, Hermanos Maristas en Carballiño y Ourense, y monjas Adoratrices en la misma capital; generosa protección al Círculo Católico de Obreros, fomento de Sindicatos agrícolas, construcción de la iglesia de Mirallos y restauración de otras varias... ${ }^{76}$.

Tal es a grandes rasgos el cuadro de la actividad episcopal del Dr. Ilundain, un obispo de cuerpo entero, que se desvela por el prestigio de los sacerdotes, sus cooperadores, y la vida espiritual de sus diocesanos. ¿Por qué, entonces, sucesos virulentos como los de Oseira? El Siglo Futuro responsabiliza de tales sucesos a los periódicos liberales de Madrid y de provincias, tomando por base la información de El Miño, que ha dado cuenta de éstos en la forma «apasionada, sectaria é injuriosa que tienen por costumbre, hasta el punto de engañar y sacar de sus casillas á viejos y cachazudos senadores; y como pudieran tan falsos relatos sorprender la buena fe y aun extraviar la opinión de las personas sensatas, conviene exponer los hechos una y otra vez, con claridad meridiana, para que resplandezca la verdad y caiga la vindicta pública sobre los verdaderos culpables» ${ }^{77}$.

Todo comienza a raíz de las obras de restauración que acomete mons. Ilundain en las iglesias de Oseira y Xunqueira de Ambía. Oseira es una parroquia del municipio de Cea, partido de Carballiño, provincia y diócesis de Ourense, donde hay un famoso monasterio de monjes Bernardos, que se llamó imperial por haberlo dotado en 1137 el emperador Alfonso VII. Destruida por un incendio su antigua fábrica en 1552, se reedificó de nueva planta con tal grandeza y magnificencia que

${ }^{76}$ El Siglo Futuro. Segunda Época III, 533 (Madrid, 7 mayo 1909), en ASV, Arch. Nunz. Madrid, busta 700 , tit. VII, rub. II, sez. I, fasc. 3, n. 6 .

${ }^{77}$ Ibíd., n. 6. 
mereció ser llamado el Escorial de Galicia. Hasta hace poco, quien deseara conocer la historia de su fundación, antigüedad y progresos, tenía que leer la obra de Peralta $(1677)^{78}$.

Su extinción como tal monasterio, se debió a los liberales del siglo XIX, que siendo algunos amigos de las riquezas de los monasterios, sucedió que ciertos perdularios se improvisarían como ricos personajes. Sufrió este monasterio, como casi todos, los golpes de la piqueta revolucionaria, conservándose intacta su monumental iglesia, cuya magnificencia y belleza no acababan de ponderar los que entendían de arte hasta hace poco. Gracias a su sucesor, mons. Cerviño, volverán los monjes cistercienses a Oseira, celebrándose gozosamente en este año el 75 aniversario de su restauración.

Cubriendo el altar mayor de tan grandioso templo había un enorme baldaquino, pabellón, dosel, como se le quiera llamar, de estilo churrigueresco, que lo afeaba lastimosamente, en opinión de los arqueólogos, y además amenazaba ruina, según denuncia escrita del arquitecto diocesano, don Daniel Vázquez Gulías. Girando el pasado año la visita pastoral, pudo cerciorarse mons. Ilundain del estado ruinoso y antiestética situación de aquel armatoste. También quiso saber el parecer del ilustre arqueólogo don Marcelo Macías, vicepresidente de la Comisión de Monumentos, quien la dio por escrito, confirmando el ningún mérito artístico de aquella mole, con cuya desaparición ganaría mucho la perspectiva de los ábsides. Lo mismo afirman el conocido arqueólogo señor Ferreiro y otros entendidos ${ }^{79}$. Con esto ordenó el prelado que se bajase el mentado baldaquino sin tardanza, para que los visitantes pudiesen admirar ya este año la prístina suntuosidad del templo. ¡Cuán lejos estaba de imaginar que restauración tan acertada y laudable pareciese a nadie mal, ni menos que pudiera acarrearle inmensas amarguras y ocasionar tremendas desgracias!

En Xunqueira de Ambía, parroquia del arciprestazgo de Allariz, hay también una iglesia que, aunque de menor suntuosidad, es de gran importancia artística, por datar del año 1164 y ser de estilo románico-gótico. Allí también ocurría lo que en Oseira, la ventanería y arcaturas del ábside circular se hallaban malamente cegadas por un deteriorado retablo de estilo plateresco, labrado en 1537. Se había pensado sustituirlo con un altar-templete de estilo románico, como la iglesia, habiendo

78 Tomás DE Peralta, Fundación, Antigüedad y Progresos del Imperial monasterio de Nuestra Señora de Ossera, de la Orden del Cister, Madrid 1677; en la actualidad, cfr. Miguel Romaní MartíNEZ, El monasterio de Santa María de Oseira (Ourense). Estudio histórico (1137-1310), Santiago de Compostela 1989, I-II.

${ }^{79}$ Laureano Tovar GonZÁlez, Ensayo biográfico del Emmo. Señor Cardenal Ilundain y Esteban, Obispo que fue de Orense y Arzobispo de Sevilla, o.c., p. 91. 
merecido el proyecto la aprobación del prelado y de los arqueólogos Sres. Macías y Marquina. Por supuesto, el coste de las obras corría en gran parte a cargo del obispo Ilundain, contribuyendo también los feligreses con donativos voluntarios ${ }^{80}$.

En este contexto, se sitúa la campaña orquestada por «El Miño» contra el prelado auriense. Dice El Siglo Futuro, al respecto: «de tiempo atrás, pero con mayor descaro desde que hubo merma de suscripciones, á consecuencia de haber publicado un blasfemo discurso del impío Dicenta, que levantó protestas en toda la Diócesis, viene tratando al Prelado con incorrección, grosería y saña, dignas de cualquier papelucho rabiosamente anticlerical. Y como anda á caza de ocasiones para molestar al Obispo, aprovechó la de las obras proyectadas en Junquera de Ambía y Osera, para zaherirle hipócritamente, á pretexto de defender monumentos arqueológicos» ${ }^{81}$.

\section{b) Relación de los hechos}

Departiendo el prelado con el señor arquitecto diocesano sobre las bellezas de nuestros templos, recayó la conversación sobre el histórico de Oseira, lamentando amargamente que el baldaquino que cubre el altar mayor, impidiera la contemplación del artístico ábside, aparte de constituir además un grave peligro por amenazar ruina inminente. Pasó el tiempo, sin volver a tratar este asunto, y el señor obispo hizo la visita pastoral a la parroquia de Oseira. Al entrar en su monumental templo y disponerse a celebrar el Santo Sacrificio, los señores Ecónomo, Arcipreste y otros varios sacerdotes de aquella comarca que le acompañaban, le advirtieron que no lo hiciese en el altar mayor porque el baldaquino amenazaba desplomarse al peso de los años y a los constantes trabajos de la roedora polilla ${ }^{82}$. El prelado auriense, dispuesto a sacrificar su peculio hasta donde fuera preciso y tras conocer el dictamen de varios arquitectos, ordenó al ecónomo que diera comienzo a las obras para retirar el baldaquino a otro lugar del templo. Tal proceder tiene lugar en aras del arte y de la seguridad pública.

El ecónomo cumpliendo aquella prescripción, inició las obras, sin protesta ni observación alguna de sus feligreses, hasta que a los tres o cuatro días se le presentó una comisión de éstos exigiendo que cesaran y no se le tocara al repetido balda-

${ }^{80}$ Benito Fernández Alonso, Junquera de Ambía, en BCMO II (1902-1905), pp. 329-332, 345350; Arturo VÁzquez NúÑEz, La ex Colegiata de Junquera de Ambía, en BCMO I (1898-1901), pp. 297-310.

${ }^{81}$ El Siglo Futuro. Segunda Época III, 533 (Madrid, 7 mayo 1909), en ASV, Arch. Nunz. Madrid, busta 700, tit. VII, rub. II, sez. I, fasc. 3, n. 6.

${ }^{82}$ Al pueblo sensato de Orense. La verdad en su punto, Orense: Imprenta El Eco de Orense, en ibíd., f. 33r. 
quino. El asunto tomó tal sesgo que el ecónomo creyó prudente ausentarse de la parroquia, porque su seguridad personal peligraba ${ }^{83}$. En este estado vino a Ourense a conferenciar con el prelado, una comisión de los feligreses de Oseira, dirigida por don Agustín Sánchez, juez municipal de Punxín, para manifestar sus deseos contrarios a la traslación del baldaquino; pero el prelado les expuso tales razones de arte, de conveniencia, de utilidad, que, no sólo depusieron su actitud, sino que allí mismo y ante otras personas que presenciaban la entrevista manifestaron su conformidad con los proyectos del obispo a la vez que le testimoniaron su agradecimiento por sufragar dichas obras ${ }^{84}$.

¿Por qué estos mismos vecinos, que allí se convencieron de la razón y buena voluntad del prelado, siguieron oponiéndose algunos días después a su proyecto? Dice literalmente el manifiesto de varios católicos ourensanos: «¿Por que á sus rústicas inteligencias habían llevado con fines bastardos la creencia de que el Obispo les engañaba, de que se pretendía robarles el mejor tesoro que encerraba su monasterio y que debían defenderlo á toda costa?» Entre los vecinos de Oseira había elementos perturbadores, alguno de ellos extraño a la parroquia, que con deliberados propósitos personales tenían empeño en sostener la agitación del pueblo y sus invenciones y alarmas para desprestigiar la autoridad del obispo y del gobernador, retadas en público por sus correligionarios y defensores en Ourense ${ }^{85}$.

En las varias conferencias que las dos autoridades tuvieron sobre esta cuestión, y después de estudiar los informes y el estado de cosas, habían convenido que era necesario restablecer el orden y la tranquilidad en Oseira, y que incluso no haciendo ahora las obras seguirían los vecinos en completa desconfianza sostenida por los cabecillas. Todo hacía suponer que el pueblo no haría oposición violenta a las obras, pues siendo sus temores que de allí se intentase sacar algún objeto, se limitaría a velar el trabajo de los operarios. Al mismo tiempo se confiaba en que una vez realizadas las obras, y visto por el vecindario que todo lo prometido era verdad, renacería la calma en la parroquia y la confianza de los fieles en su cura se restablecería ${ }^{86}$.

Por todos estos considerandos entendió el gobernador que se debían hacer las obras cuanto antes, tomando las debidas precauciones para que los cabecillas del

${ }^{83}$ Cfr. Miguel Ángel GonZÁlez García, El antes y el después del baldaquino de Oseira, en «Abrente» 12 (A Coruña, 1980), pp. 183-209.

${ }^{84}$ Al pueblo sensato de Orense. La verdad en su punto, Orense: Imprenta El Eco de Orense, en ASV, Arch. Nunz. Madrid, busta 700, tit. VII, rub. II, sez. I, fasc. 3, n. 6, f. 33r-v.

${ }^{85}$ Laureano Tovar GonZÁLEZ, Ensayo biográfico del Emmo. Señor Cardenal Ilundain y Esteban, Obispo que fue de Orense y Arzobispo de Sevilla, o.c., pp. 92 y ss.

${ }^{86}$ Carta del nuncio apostólico de Madrid al secretario de estado. Madrid, 9 de mayo de 1909, en Arch. Nunz. Madrid, busta 700, tit. VII, rub. II, sez. I, fasc. 3, n. 6, ff. 15r-29r. 
conflicto no intentasen alguna agresión contra los obreros. Por otra parte, había manifestado repetidas veces el vecindario de Oseira, que contra la fuerza armada no harían nada, y las personas conocedoras de aquel país opinaron siempre que la sola presencia de la Guardia Civil evitaría los desmanes de los exaltados. Sentadas estas bases y en la seguridad de que nada hacía temer desgracias personales, el obispo Ilundain dispuso que saliesen los obreros para Oseira, y pidió al gobernador que, por los medios que creyese oportunos, garantizase la seguridad personal de estos obreros en previsión de que pudiesen ser agredidos por aquellos interesados en dificultar la solución pacífica de la llamada cuestión de Oseira ${ }^{87}$.

¿Por qué resultaron fallidos los razonamientos de las autoridades? ¿Por qué los habitantes de Osera trataron de impedir a la fuerza la bajada del baldaquino? ¿Por qué se negaron a toda razón y, poseídos de una excitación loca, no respetaron consejos y se olvidaron de la conformidad, que en otras ocasiones habían demostrado? ¿Por qué los hombres estaban parapetados dentro del templo y encaramados en sus columnas con latas de petróleo, hoces, hachas y otras armas, y tenían a las mujeres y niños en el atrio y en las entradas para oponerse al paso de los obreros y la guardia civil? ¿Por qué aquellas pobres gentes, que defienden un baldaquino destartalado y sin mérito, intentaban quemarlo después? ¿Quién se encargó de borrar de sus ánimos los frutos que se habían obtenido en sus entrevistas con el obispo, con el gobernador y con las personas de buena voluntad, emisarias de las dos autoridades?

El destacamento de la Guardia Civil que al mando del teniente Salinas salió de Ourense custodiando a los carpinteros llegó a Cea a las cinco y media de la madrugada del día 22 de febrero de 1909. Allí se detuvieron los expedicionarios, almorzando y cargando de vituallas y bebidas dos caballerías menores, que los acompañaron hasta Oseira. Al llegar al monasterio se encontraron cerradas herméticamente las puertas del templo. Franqueadas las puertas, la nave del templo apareció llena de mujeres y chiquillos que gritaban pidiendo que no les tocasen a su venerable altar. El teniente Salinas -conforme a lo que se decía en su comunicación oficialdispuso una carga al arma blanca, desalojando el templo. Los carpinteros comprendiendo cuán insensata era la tentativa de poner mano en aquel altar de tan conmovedora manera defendido por aquel pueblo profundamente religioso, manifestaron al teniente Salinas su propósito de retirarse. Con los obreros desaparecía también la intervención del señor obispo ${ }^{88}$.

${ }^{87}$ Laureano Tovar González, Ensayo biográfico del Emmo. Señor Cardenal Ilundain y Esteban, Obispo que fue de Orense y Arzobispo de Sevilla, o.c., pp. 94-112.

${ }^{88}$ ABC, 27 abril 1909, p. 4, en Arch. Nunz. Madrid, busta 700, tit. VII, rub. II, sez. I, fasc. 3, n. 6, f. $31 \mathrm{r}$. 
Los que allí quedaron sabrán dar la razón de las desgracias; pero lo cierto, es que el sangriento suceso, que se lloró entonces, se desarrolló cuando los vecinos habían visto regresar a los obreros, cuando sabían que el baldaquino no bajaba de su puesto. A la marcha de los ocho obreros, la plaza que hay delante de la iglesia se hallaba ocupada por hombres, mujeres y niños, que se resistían a que nadie entrase en el templo. Con esto, permanecían allí por un lado la fuerza pública, representante de la autoridad, y por otro, la gente, seducida y exaltada por infames embaucadores. Parece ser que los grupos, envalentonados con promesas de impunidad y de que los guardias no dispararían, se propagaron a cometer desmanes, a sacar maderas de la iglesia y quemarlas a la puerta, desobedeciendo, insultando y, por último, amenazando y agrediendo a los guardias. Parece ser que agotados los recursos de la paciencia y de la prudencia, no logrando intimidar a los revoltosos ni con toques de atención, ni con una descarga al aire, sino que por el contrario arreciaban en su temeraria e inconcebible agresión, el teniente mandó hacer fuego, quedando tendidos tres cadáveres y cinco heridos de muerte ${ }^{89}$.

Aquel día mons. Ilundain terminó la visita pastoral en Parada do Sil, disponiéndose a regresar a Ourense. Entonces se enteró de lo que había ocurrido, dándose cuenta de que El Miño «excitaba á una manifestación de desagrado contra el Prelado, á la que parece se unirían los Socialistas, y los impíos. En vista de esto, varié de itinerario y vine á Allariz para dar tiempo á pensar qué debo hacer» ${ }^{90}$. El sangriento y lamentable suceso que se tenía que haber evitado a toda costa, con un poco de precaución o habiéndose retirado la guardia civil con los obreros al comprobar la actitud belicosa de los vecinos, fue aprovechado por los demagogos para atacar de una manera atroz al obispo de Ourense, inocente y ajeno a la desgracia. Por otra parte, el baldaquino permaneció en su sitio hasta que años después, en 1925, fue definitivamente quitado por el peligro evidente de derrumbe ${ }^{91}$.

El Miño, periódico de Ourense, publicó muchos sueltos y artículos contra el proyecto de retirar el baldaquino y contra la persona del obispo. Debe advertirse que El Miño era un diario anticlerical, defensor del proyecto de Ley de Asociaciones, y amparador de una escuela laica que se había establecido en Ourense, teniendo por sistema socavar la autoridad de la Iglesia, aunque en el terreno especulativo aparentase respetarla.

En este contexto se entiende el manifiesto dirigido por varios católicos ourensanos que aúnan sus plumas para que, venciendo las tensiones y la demagogia

\footnotetext{
${ }^{89}$ El Siglo Futuro. Segunda Época III, 533 (Madrid, 7 mayo 1909), en ibíd., n. 6.

${ }^{90}$ Carta del obispo de Ourense al nuncio apostólico de Madrid. Allariz, 29 de abril de 1909, en ibíd., ff. 19r-22r.

${ }^{91}$ La Región, 4577 (28 julio 1925).
} 
generada a raíz de los sucesos de Oseira, se recupere la cordura y el crédito sobre la figura del obispo Ilundain. He aquí su encabezamiento:

«Pasaron las primeras impresiones de la nunca bastante llorada jornada de Osera. Hemos observado con ánimo sereno el movimiento de la opinión orensana, justamente alarmada por los trágicos sucesos. Presenciamos con espíritu contristado los efectos que en la masa popular han producido las informaciones exageradas y subversivas que publicó un periódico. No nos asombramos del extravío mental, que las falsedades históricas y los sofismas empleados con ruin terquedad por periodistas revolucionarios, aduladores de bajas pasiones, han causado en este pueblo de sensatez y cordura proverbiales; pero creemos llegado el momento de publicar la historia fiel y exacta del desarrollo de los acontecimientos, para que se juzgue imparcialmente, desprovisto el corazón de todo apasionamiento y con conocimiento de causa, la parte de culpa que alcanza á la alta personalidad, contra quien se dirigen los esfuerzos de los sectarios, ávidos siempre de desprestigiar á la autoridad eclesiástica y de sembrar en los ánimos de los fieles gérmenes de odio, que más tarde pudieran convertirse en faltas de acatamiento y respeto, y llevarlos á engrosar las filas de los enemigos del orden, de la moralidad y de la religión» ${ }^{92}$.

\section{c) En Nunciatura y Secretaría de Estado}

Aquel tema fue llevado por los liberales al Parlamento, donde se prodigaron los discursos atacando al gobierno conservador y al obispo de Ourense, una víctima más de aquellos sucesos. En defensa de mons. Ilundain salió el obispo de MadridAlcalá Salvador y Barrera, que lo hizo brillantemente en el mismo Parlamento ${ }^{93}$.

Por otra parte, el nuncio apostólico de Madrid informó puntualmente a su eminencia Merry del Val del estado de ánimo del prelado auriense. El baldaquino de Oseira no fue más que el pretexto para tales sucesos -opina el nuncio-, puesto que la verdadera causa de esta rebelión reside a su parecer en las urgentes reformas a las cuales el obispo mete mano en relación con el clero, en las conspiraciones política entre liberales y conservadores, así como en la índole de aquellos habitantes, los cuales si aprueban individualmente las disposiciones de la autoridad eclesiástica, se abstienen de aprobarlas en público, apenas se ven contradichas ${ }^{94}$.

Prueba de ello, es que los canónigos presentaron uno a uno sus condolencias al prelado, pero no quisieron hacerlo capitularmente. Otra manifestación descortés

\footnotetext{
${ }^{92}$ Al pueblo sensato de Orense. La verdad en su punto, Orense: Imprenta El Eco de Orense, en ibíd., f. 33r.

${ }^{93}$ Laureano Tovar González, Ensayo biográfico del Emmo. Señor Cardenal Ilundain y Esteban, Obispo que fue de Orense y Arzobispo de Sevilla, o.c., p. 108.

${ }^{94}$ Carta del nuncio apostólico de Madrid al secretario de estado. Madrid, 6 de julio de 1909, en ASV, Segr. Stato, 1909, 249, fasc. 1, ff. 217r-220r (n. ${ }^{\circ}$ protocolo 38671).
} 
del cabildo catedralicio corresponde a que el año anterior, por disposición del Sínodo Diocesano en conformidad con el derecho canónico, se dispuso que la paga por la ausencia de los canónigos del coro, se vertiera en la masa común. Hoy el capítulo exige que se respete el uso vigente, y que aquella paga se distribuya inter presentes, como si el mismo capítulo no hubiera ya dado su aprobación a aquel Sínodo. También precisa que por ahora ha suspendido la visita pastoral y otras medidas, puesto que el desafecto hacia su persona es grande en la mayor parte de la diócesis ${ }^{95}$.

El interés del nuncio por el estado de ánimo del obispo Ilundain también se puede seguir a través de la correspondencia personal entre ambos. Sin duda, la perspectiva de los sucesos de Oseira a través del principal implicado en todo aquel embrollo puede darnos cierta luz sobre algunos aspectos de máxima importancia que bien seguro se escaparían a la prensa y a las crónicas de comienzos de siglo, más pendientes de la desfiguración de los hechos que de la verdad de los mismos.

A poco tiempo de aquella tragedia, desde su residencia en la villa de Allariz, mons. Ilundain agradecía que fuera reaccionando la opinión sensata, que el clero se apresurara a testimoniar su adhesión al prelado y su protesta contra las difamaciones de que era objeto por la prensa impía. También agradecía la visita del gobernador civil en compañía del alcalde de Ourense, quienes le aconsejaron que no regresara a la ciudad episcopal hasta pasado el 1 de mayo. Desde esta especie de exilio temporal, don Eustaquio no dejó de preocuparse por las familias de las víctimas, y así envió a Ourense una circular para que fuera publicada en el Boletín Eclesiástico a fin de abrir una colecta que paliara las consecuencias negativas de esta desgracia. La referida colecta la encabezó él mismo con la cantidad de cinco mil pesetas, además del encargo de varios sufragios. Por otra parte, le tranquilizaba que hubiera terminado el debate en el Senado a la vez que se sentía confortado por el extenso telegrama que le había remitido el ministro de Gracia y Justicia en tan luctuosas circunstancias ${ }^{96}$.

El 4 de mayo de 1909, casi tres meses después, el obispo Ilundain regresó a Ourense acompañado del alcalde de esta ciudad y de unos buenos amigos en cuyo automóvil hizo el viaje sin que nadie le molestase, no teniendo lugar ninguna demostración de desagrado contra su persona desde su venida. En carta privada al nuncio, el prelado auriense sintetiza los hechos acaecidos por la feroz persecución contra él en datas pretéritas: «desahogar su veneno por haber pintado en mi Dióce-

${ }^{95}$ Ibíd., ff. 219v-220r.

${ }^{96}$ Carta del obispo de Ourense al nuncio apostólico de Madrid. Allariz, 29 de abril de 1909, en Arch. Nunz. Madrid, busta 700, tit. VII, rub. II, sez. I, fasc. 3, n. 6, f. 17r. 
sis varias casas de HH. de las Escuelas Cristianas y Maristas; manifestar su disgusto contra mi Provisor que ha escrito algunos escritos en uno de los diarios de Orense, si bien desde hace bastante tiempo se abstuvo de ello por habérselo yo prohibido, á fin de que no comprometiese, con fines buenos si pero no indispensables, la libertad de mi acción pastoral si los impíos se sentían molestados con tales escritos; excitar á los sacerdotes que han recibido algun correctivo en una u otra ocasión de su Prelado; adquirir popularidad el Miño entre las gentes del pueblo y sumar votos en las elecciones populares $»^{97}$.

Otro testimonio de los incidentes acaecidos contra el obispo Ilundain, pocos días después de su venida, lo recoge escueta, pero contundentemente el telegrama que dirige al nuncio apostólico de Madrid el 6 de mayo de 1909. He aquí su contenido: «anteayer noche durante mas de dos horas multitud no muy considerable recorrio la ciudad dando silbidos y gritos contra la religión y personas sagradas apedreando y causando destrozos palacio episcopal, seminario, casas religiosas y benéficas, círculo católico y se ensañaron principalmente en el colegio maristas. Anoche reinaba tranquilidad. Inmensa mayoria vecindario protesta y me visita. El obispo» ${ }^{98}$.

Más adelante, el 21 de mayo de 1909, don Eustaquio se desahoga por escrito ante el nuncio apostólico por los sinsabores y ultrajes de que viene siendo víctima en esta temporada. Manifiesta que muchos fieles, especialmente los de las clases populares y los campesinos «alucinados por la prensa y seducidos por la maledicencia, que ha clavado su diente venenoso en mi persona y aun en los autos de gobierno mas laudables realizados durante mi Pontificado, han participado de la atmósfera envenenada contra su Prelado». La calma se va restableciendo, pero se necesitará mucho tiempo para que mons. Ilundain recobre el buen nombre y prestigio que tuvo hasta hace poco tiempo. Al respecto, es ilustrativo el contenido de la posdata de esta carta: «P.D. Llevo veinte días encerrado en mi Palacio». Trabaja en estos momentos para que se logre el silencio de El Miño e incluso que este periódico, que tiene muchos lectores en la diócesis, reintegre como sea factible el buen nombre del prelado. Para conseguirlo se han dado muchos pasos por personas prestigiosas y en la espera de algún resultado favorable ${ }^{99}$.

En este sentido, don Eustaquio ha tenido varias conferencias secretas con el Director de El Miño y el asunto parece ser que va por buen camino, ya que en esas

${ }^{97}$ Carta del obispo de Ourense al nuncio apostólico de Madrid. Allariz, 4 de mayo de 1909, en ibíd., f. 23r.

${ }^{98}$ Telegrama del obispo de Ourense al nuncio apostólico de Madrid. Orense, 6 de mayo de 1909, en ibíd., f. 23r.

${ }^{99}$ Carta del obispo de Ourense al nuncio apostólico de Madrid. Orense, 21 de mayo de 1909, en ibíd., f. 26v. 
conferencias le ha manifestado dicho señor que irá atenuando la oposición al procurar que la fama del obispo se venga restableciendo. Hasta tal punto llega la ignominia que, después de los desaguisados referidos, mons. Ilundain comunica muy reservadamente al nuncio la siguiente manifestación:

«dicho Director me ha formulado una aspiración que sería para él, si la viese lograda, un bien grandísimo. Yo me he ofrecido á interesarme en su favor, porque lo he visto muy conforme á la caridad de un Prelado y muy conducente para restablecerse la tranquilidad. Dn. Francisco Álvarez de Novoa, Director de El Miño de Orense desea ardientemente ser nombrado Cónsul de España en Rio Janeiro (Brasil) y si esto no es posible, en Santos. El solicitante posee el español, portugués, italiano y francés y ha residido cinco años en Portugal, cuya legislación conoce. Es hijo del coronel de la Guardia Civil (ya fallecido) D. Victor Álvarez de Novoa. Tiene aprobados varios años de la Facultad de Derecho. Me pide secreto sobre esta intervención mía en su pretensión. Vea, mi venerado Sr. Nuncio, si puede V. E. conseguir para el solicitante Dn. Francisco el cargo á que aspira. Yo ruego á V. E. con todo encarecimiento que interceda con el Sr. Ministro de Estado. Yo escribiré mañana al Sr. Presidente del Consejo de Ministros con el mismo objeto. La campaña contra mí ha sido hecha por dicho Director de El Miño: hoy está en buenas disposiciones para que cese dicha campaña; me ruega apoye su intención y parece ser esta solución muy pacificadora» ${ }^{100}$.

\subsection{Voluntad de un traslado}

Es de máximo interés el parecer del obispo Ilundain tras el paso de seis meses de los sucesos de Oseira. En una carta que el propio prelado tilda de «confidencial y personal» describe su situación actual en la diócesis de Ourense. Reconoce que el silencio de la prensa durante este verano, la mudanza de gobernador civil y el cansancio de la lucha antiepiscopal han producido alguna mejora en el espíritu público con relación a su persona. En este sentido, ha podido salir a la calle y a las iglesias de la ciudad varias veces, sin que se hayan producido manifestaciones de hostilidad o desagrado, fuera de algunas descortesías de algunos jóvenes o sectarios.

No obstante lo que acaba de manifestar el obispo Ilundain, también hace saber al nuncio que si por el momento presente la situación ha mejorado algo respecto de su persona, esta mejora es más superficial que profunda, puesto que, tal como él mismo asevera, «tanto el ejercicio de mi ministerio, como mi libertad de acción pastoral y mi prestigio é influjo moral han recibido tal quebranto con la sabida persecución que clérigos y seglares fomentaron, que es dificilísimo poder recobrar

${ }^{100}$ Ibíd., ff. 25r-26v. 
aquella libertad de accion y el prestigio y ascendiente moral que antes poseía, los cuales son muy necesarios para regir diócesis tan vasta y en país gallego. Posible es que mi misión aquí haya terminado» ${ }^{101}$.

Mons. Ilundain se funda para hacer estas afirmaciones en una serie de observaciones, que le sugieren su propia experiencia e indagación de persona sensata. Por una parte, observa que una porción numerosa de sus sacerdotes tiene notable y evidente desafecto y prevención contra él, y contra su sistema de gobierno, por lo cual existe poca cordialidad con su prelado, resintiéndose el espíritu de reverencia y obediencia. Por otra parte, los pueblos, que en su mayoría son rurales en esta diócesis, son muy tenaces en sus prejuicios y pasiones, y por consiguiente, después de la difamación producida y sostenida por los sucesos de Oseira, resulta casi imposible que dejen de juzgar a su obispo a través del prisma de aquellos prejuicios y apasionamientos, procurando aprovechar aquellas circunstancias, cuando les conviene al sentirse por poca cosa molestos con sus medidas pastorales.

La tragedia de Oseira fue explotada por la prensa liberal como arma política contra el gobierno de Maura-La Cierva. Eugenio Montero Ríos instó a su jefe político en Ourense y dueño del periódico El Miño, don Vicente Pérez, a que no cesaran en la campaña contra el obispo y el gobernador. Incluso medio año después, los elementos liberales y radicales dan muy pocas muestras de haber depuesto su animosidad; antes, al contrario, se vio precisado el gobernador civil a refrenar a los directores del movimiento hostil al prelado que intentaban realizar una manifestación pública de desagrado, tan pronto como éste regresó a Ourense hace dos semanas, siendo necesario aplacar al periódico El Miño que con malévolas insinuaciones comenzaba a renovar la campaña difamatoria. Concluye el prelado en su carta que «todo lo mal hace fundadamente presumir que, cuando el Partido Conservador abandone el poder, quedaré á merced de los caprichos de mis adversarios, y estos evocando los sucesos de Osera y tergiversando y facilitando su explicación harán imposible mi ministerio, con la aquiescencia de no pocos Eclesiásticos» ${ }^{102}$.

En suma, la situación que se había creado era muy difícil, por lo que consideraba que su libertad de acción estaba embarazada, y el terreno muy minado, por lo que se veía impedido para resolver asuntos arduos de carácter general de gobierno. Con motivo de las acusaciones dirigidas injustamente contra él, se hicieron gestiones para trasladarlo en 1914 a Palencia, hablándose también de Zamora, pero ambas propuestas quedaron sin efecto. El nuncio le expone sus intenciones en los

${ }^{101}$ Carta del Obispo de Ourense al nuncio apostólico de Madrid. Orense, 24 de septiembre de 1909, en Arch. Nunz. Madrid, busta 703, tit. VII, rub. II, sez. III, fasc. 4, n. 53, f. 81r.

${ }^{102}$ Ibíd., ff. 81v-82r. 
siguientes términos: «tengo el honor de manifestarle que es intención de la Santa Sede trasladarle à V. E. a otra Sede Obispal donde con mayor sosiego podrá ejercer su bien reconocido celo pastoral. En principio se pensó en hacer la translación à la Diócesis de Palencia, que se quedará vacante; pero ahora parece mejor su promoción á la de Zamora»103.

La respuesta del Dr. Ilundain es concluyente: «manifiesto á V. E. que con mucho agrado por mi parte estaré dispuesto a ser trasladado á la sede de Palencia (...). Pero por lo que hace al Obispado de Zamora me creo en el deber de manifestar á V. E., despues de pensarlo deternidamente (...), y en el conocimiento que tengo de cosas y personas, y reciprocidad de relaciones de las provincias de Zamora y Orense, que son limítrofes entre sí, abrigo una conviccion firmísima de que nada se conseguirá en orden a los fines indicados por V. E. ni en bien mío, con mi traslado a Zamora. (...) que me permita le diga, abriendo mi corazon, que siento repugnancia racional insuperable para ocupar la Sede de Zamora» ${ }^{104}$.

Por su parte, el obispo auriense informa al metropolitano de Burgos de su angustia por la marcha para Zamora, por lo que el arzobispo de Burgos aboga por su traslado para Palencia. Sin embargo, a última hora tal posibilidad no será bien vista al asegurársele que «el Ylmo. Sr. Iluldain no sería bien recibido en Palencia, y su ministerio pastoral encontraría muchas dificultades. En vista de lo cual le había ofrecido la vacante Diócesis de Zamora, pero como él me escribe que no puede aceptar, creo que la solución por el momento será dejarle en Orense» ${ }^{105}$.

\subsection{Otros episodios: Marrubio y Lapela}

La sombra de los sucesos de Oseira es alargada. En este sentido, basta referir el caso de la protesta de una comisión de vecinos encabezada por el alcalde a favor de la parroquia de San Andrés de Marrubio. La causa es el descontento con el nombramiento del nuevo párroco que goza de mala fama «por su desmedida aficción al alcohol embriagándose frecuentemente y otros vicios, que en respetuosa exposición que hemos elevado á nuestro R. Prelado en Marzo del mismo año hemos expuesto» ${ }^{106}$.

103 Carta que recoge la propuesta del nuncio para la traslación de mons. Eustaquio Ilundain. Madrid, 20 de febrero de 1914, en ASV, Arch. Nunz. Madrid, busta 717, pos. 2: vescovi, fasc. 1, Orense, f. $389^{\mathrm{a}}$.

104 Carta del obispo Ilundain al nuncio de Su Santidad. Orense, 24 de febrero de 1914, en ibid., f. $393 \mathrm{r}$.

105 Carta del nuncio apostólico de Madrid al arzobispo de Burgos. Madrid, 28 de febrero de 1914, en ibid., f. 391r.

106 Carta del alcalde de Barrio al nuncio apostólico de Madrid. Vilar de Barrio, 5 de marzo de 1911, en Arch. Nunz. Madrid, busta 703, tit. VII, rub. II, sez. III, fasc. 4, n. 53, f. 103r. 
Al ser infructuosa la primera exposición de los vecinos de Marrubio ante el obispo Ilundain, entregada en mano por una comisión de seis de los más respetables de esta parroquia a pesar de que distan de Ourense unos setenta kilómetros, se entregó a últimos de febrero de 1911 una denuncia formal y fundada en el Derecho Canónico en la Secretaría de Cámara para que pasase al Provisorato. Poco después, se notificó una respuesta del prelado que decía «no parecer causas suficientes para la incoacion del referido expediente» ${ }^{107}$.

Al efecto, se organizó en esta parroquia una manifestación de protesta contra dicho cura y el obispado. Más de mil personas recorrían la parroquia en perfecta organización «dando vivas á la religión, al Papa y á los buenos Sacerdotes, y protestando contra la embriaguez, los malos curas y desafueros del Obispo». Durante la misma repartieron pasquines, así como estandartes alusivos al acto, entre los que había uno que decía: «Recuerda lo de Osera» ${ }^{108}$.

Los fondos vaticanos documentan otro episodio de cierta dificultad para el pontificado del obispo Ilundain al exigir la población de Lapela la segregación del anejo San Antón de Remoíño, ante lo que el coadjutor se opone ${ }^{109}$. El prelado auriense lamenta la obsesión con que se ha tratado este tema y que en verdad ha provocado ciertos excesos, calificados como «irrespetuosos», para con el nuncio apostólico de Madrid ${ }^{110}$. Por su parte, el nuncio se alegra de que el citado expediente haya pasado al fiscal eclesiástico de la diócesis auriense, lo que celebra augurando que el asunto se resuelva con satisfacción para todos ${ }^{111}$.

En concreto los vecinos de Lapela llegaron a enviar una exposición impertinente y amenazadora en la que se le decía al nuncio que si la autoridad eclesiástica no accedía a sus deseos para el 15 de octubre, llamarían a Lapela un ministro protestante que se encargara de la capilla existente en el pueblo, y que a partir del primero del mismo mes ningún vecino habría de ir a misa a Remoíño. Frente a estas imposiciones, el nuncio mons. Ragonesi acogió con cierto alivio la siguiente exposición de un tono más moderado. Así, a su juicio, consideraría prudente el que se volviera a estudiar aquel asunto de tal manera que la población de Lapela se reintegrara a la iglesia matriz de Arnoia, poniendo fin a un pleito que había sido causa

${ }^{107}$ Ibíd., f. 103r-104r.

108 Ibíd., f. 104v.

109 Carta de la población de Lapela al auditor de Nunciatura. Lapela, 10 de noviembre de 1916, en Arch. Nunz. Madrid, busta 743, fasc. 1, pos. 203, ff. 61r-62r.

${ }^{110}$ Carta del obispo de Ourense al nuncio apostólico de Madrid. Orense, 24 de octubre de 1916, en ibíd., f. 64.

${ }^{111}$ Carta del nuncio apostólico de Madrid al obispo de Ourense. Madrid, 30 de octubre de 1916, en ibíd., f. 65r. 
de disgustos para el prelado de Ourense y también de menoscabo para los intereses de la Iglesia ${ }^{112}$.

El problema en cuestión tenía su origen en el arreglo parroquial de 1893 del obispo Cesáreo al hacer depender esta población del anejo de San Antón de Remoíno y no de la parroquia matriz de San Salvador de Arnoia. El finado mons. Carrascosa prometió resolver esta situación al girar la visita pastoral. Por desgracia, esta visita nunca llegó a realizarse al fallecer el mentado prelado antes de venir a esta comarca $^{113}$.

La comunicación entre Lapela y la iglesia matriz no se había interrumpido como se afirmó. Existía sobre el río Arnoia un pasaje de piedra de sillería de más de un metro de ancho, que incluso, en época de extraordinaria inundación, las aguas del río no lograban rebosar quedando siempre expedito el camino del puente para poder administrar los auxilios espirituales si fuere menester a algún enfermo. También alegó que no se había informado convenientemente de que hacía tres años el puente de Arnoia, que amenazaba ruinas desde hace más de diez, se derrumbó incomunicando asi al pueblo de Remoiño con la iglesia matriz en cuyo atrio se daba sepultura a todos los cadáveres de la parroquia. Esta incomunicación duró medio año, hasta que se tendió sobre las mismas ruinas un puente de madera de pino, que actualmente es un verdadero peligro. Durante dicha incomunicación tuvieron que ser conducidos al cementerio parroquial dos cadáveres del pueblo de Remoiño por nuestro pasaje de piedra, única comunicación sólida existente en la actualidad ${ }^{114}$.

Por otra parte, el informe técnico de las distancias que median entre Lapela y Remoíño, y de la iglesia matriz a Lapela, no es exacto. Tal desajuste se explica fácilmente al haber sido tomadas tales medidas por el perito agrícola Sr. Reivelo, hermano del coadjutor de Remoiño. Además, más corto o más largo uno u otro camino, este pueblo desea pertenecer, como siempre perteneció, a la iglesia matriz. Aquella comisión atestigua que desde su pueblo escuchan perfectamente el sonido de sus campanas, a la vez que con cierto apresuramiento pueden llegar a tiempo a la hora en que se celebra la Santa Misa. En cambio, entre Lapela y Remoiño se interpone una alta montaña que impide ver y escuchar el sonido de las campanas, y el camino que a dicho anejo conduce, es de lo peor que se conoce en la region, lleno de rocas escarpadas, tardando una hora. Por tanto, se trata de un camino infranqueable para niños y ancianos. Por otra parte, si el prelado concede el bau-

112 Carta del nuncio apostólico de Madrid al obispo de Ourense. Barcelona, 18 de octubre de 1916, en ibíd., f. 70r.

${ }^{113}$ Carta de la comisión de Lapela al nuncio apostólico de Madrid. Lapela, 14 de octubre de 1916, en ibíd., ff. 71r-72r.

${ }^{114}$ Ibíd., f. 72r-v. 
tismo, el matrimonio y el precepto pascual, a cuantos lo deseen en la iglesia matriz, ¿por qué no el precepto dominical? Además, sólo hay un sacerdote para Remoíño y Lapela, mientras que para el resto de la parroquia están el párroco, dos capellanes y tres sacerdotes más ${ }^{115}$.

El canónigo secretario, don Jesús Gozalo, había empezado a tramitar este asunto en connivencia con el obispo Ilundain. En este contexto, se entiende la exposición del 12 de junio de 1916 en que se hace una relación de todos los pasos dados hasta ahora. He aquí su contenido:

«1. Que ya en 17 de Enero de 1906 decretamos haber lugar á acceder á la instancia análoga á la presente en que se Nos pedía la segregación del pueblo Lapela de la iglesia de Remoiño; respetando por causas razonables para Nos lo dispuesto no hace muchos años por nuestro V. antecesor Exmo. Sr. Don Cesáreo Rodrigo muy conocedor de la diócesis cuyo arreglo parroquial hizo; y conformándonos asi tambien con lo decretado por nuestro V. Predecesor Don Pascual Carrascosa en este asunto. 2. ${ }^{\circ}$ Que por sucesivos decretos hemos concedido á los vecinos de Lapela como ellos lo confiesan amplia facultad para que reciban los Sacramentos en la iglesia matriz de Arnoya, siempre que les plazca asistir á ella para comulgar, aun en tiempo pascual, y para llevar á sus niños á ser bautizados en la misma iglesia matriz de Arnoya, asi como para recibir sus vecinos el Santo Sacramento del matrimonio en ella cuando lo soliciten del Sr. Párroco de Arnoya en atención á ser matriz de Remoiño. 3..$^{\circ}$ Que con posterioridad á algunas de las instancias en que los mencionados vecinos de Lapela nos pidieron la segregación de la iglesia de Remoiños y su incorporación á Arnoya, se ha ensanchado notablemente el templo de Remoiño y se han hecho mejoras para el mejor servicio de los fieles de dicho anejo, cuyo Coadjutor está siempre á disposición de los vecinos de Lapela para todo servicio espiritual. $4 .^{\circ}$ Que aunque Nos no podemos imponer obligación á los Sacerdotes para que celebren santo sacrificio de la Misa en la Capilla situada en el pueblo de Lapela, no ignoran los vecinos de ese pueblo que jamás puede incoarse oposición alguna nuestra á que cuando los referidos fieles de Lapela lo deseen encarguen á cualquier sacerdote habil la celebración de Misa en su Capilla previo estipendio según sea usual en casos análogos. 5. ${ }^{\circ}$ Que tenemos dadas ordenes privadas al Sr. Coadjutor de Remoiño á fin de que vaya algunas veces al pueblo de Lapela á instruir en la doctrina cristiana á los niños del pueblo para mayor comodidad y provecho» ${ }^{116}$.

A pesar de todos los argumentos referidos, los vecinos de Lapela siguieron arguyendo las razones arriba expuestas al prelado auriense, además de concluir

\footnotetext{
115 Ibíd., ff. 72v-73r.

${ }^{116}$ Carta del secretario del obispado de Ourense al nuncio apostólico de Madrid. Orense, 14 de junio de 1916, en ibíd., ff. 78v-79r.
} 
que: «antes del arreglo parroquial pertenecimos siempre á la Yglesia matriz que atendió á este pueblo con gran cariño, y á la rivalidad existente entre Remoiño y nosotros, rivalidad que tuvo su origen desde la fecha del arreglo parroquial, haced que termine de una vez el estado actual de cosas, y dignaos decretar inmediatamente la segregación del Anejo de Remoiño, y por tanto, nuestra incorporación á la Yglesia parroquial de Arnoya, para todos los efectos del culto católico» ${ }^{117}$. Pocos meses después, tras la visita pastoral del obispo Ilundain y al no obtener respuesta alguna a sus demandas, los vecinos de Lapela se dirigieron a mons. Ragonesi confiando ser escuchados y dar cumplimiento a sus anhelos. Sólo en este contexto, se entiende la siguiente aseveración:

«Verdad que él es el Obispo de Orense, cuya intransigencia originó los sucesos de Osera; que por su causa se fusilaba en un sagrado recinto á hombres, mujeres y niños indefensos, y que nosotros no somos más que humildes hijos del pueblo que trabajan como los negros lo harian en las plantaciones de América en tiempos de la esclavitud, y que después de vaciar nuestros bolsillos para sostener á ese Prelado con un sueldo fabuloso, impropio de un ministro del Divino Jesús, apenas si nos queda un pedazo de pan que ofrecer á nuestros hijos. Pero el tiempo de la esclavitud cedió el paso á la rebeldía, y rebeldes somos y rebeldes seremos hasta conseguir nuestros fines» ${ }^{118}$.

Aquellos feligreses contrariados y prontos para la insumisión, también se mostraron dispuestos a acudir a la prensa liberal para que en sus columnas se señalara una vez más la terquedad de este obispo. Incluso sospechaban que los párrocos de Refoxos, Merens y San Benito do Rabiño se hubieran encargado de suplicarle al prelado la denegación de esta petición de la población de Lapela, afirmando que al de San Benito sí le llegó a prometer que no la aceptaría. La razón que han aducido es aquélla de que «en la parroquia que anteriormente regentó este sacerdote halló asilo seguro el actual Obispo de Orense después de los célebres y luctuosos sucesos de Osera, para librarse de las justas iras populares» ${ }^{119}$. Por tanto, los sucesos de Oseira constituyeron un verdadero drama, cuya sombra alargada minó la popularidad de este prelado, ciertamente autoritario, pero celoso y digno de elogio por tantos otros aciertos.

117 Carta de los vecinos de Lapela al obispo de Ourense. Lapela, 4 de julio de 1916, en ibíd., ff. 82r-83r.

${ }^{118}$ Instancia de los vecinos de Lapela al nuncio apostólico de Madrid. Lapela, 29 de septiembre de 1916, en ibíd., ff. 85r-86v.

${ }^{119}$ Ibíd., ff. 87r-89r. 


\section{BREVE CONCLUSIÓN}

El obispo Ilundain y Esteban debe ser catalogado como una de las figuras más eminentes del episcopologio ourensano en su época más contemporánea. Considero que estas páginas que revelan interesantes noticias inéditas sobre este personaje, ayudan a completar la visión que merece su fecundo y trabajado pontificado. Las fuentes documentales vaticanas propician una lectura más preclara de la azarosa actividad episcopal del Dr. Ilundain que tuvo que hacer frente a una época no fácil en que las ideas partidistas generaban comportamientos que habrían de desembocar en la guerra fraticida española.

Junto a los temas aludidos, quedan otros muchos en el tintero que futuros estudios ulteriores podrán completar esta aportación a partir de la inédita documentación diocesana. Así, por ejemplo, se manifiesta en más de una ocasión su preocupación social, puesto que ante la emigración pide que se forme bien en la fe a los niños que han de partir a otras tierras en procura de una mejor bonanza económica, a la vez que se fomenta el cooperativismo y la fundación de sindicatos agrícolas para evitar que la mano de obra ourensana se vea obligada a emigrar.

Por otra parte, su caridad fue grande y públicamente reconocida sobre todo después de su generoso y heroico comportamiento en la gravísima epidemia gripal de 1918, tras facilitar a sus expensas: albergue, cariño, alimentos, lecho y abrigo. Para ello ni siquiera se reservó el edificio del Seminario, que lo convirtió en hospital ${ }^{120}$. Este rasgo, digno de eterna alabanza, indujo a la Excma. Diputación Provincial a recoger la gratitud del pueblo ourensano, solicitando para él la Gran Cruz de Beneficencia por la abnegación y el desprendimiento mostrado en una situación tan extrema ${ }^{121}$.

En 1920 es preconizado como arzobispo de Sevilla. Su Majestad el Rey Alfonso XIII se sirve expedir con fecha del 18 de noviembre último el siguiente real decreto: «Atendiendo al celo religoso, virtud, ciencia y demás recomendables circunstancias de Don Eustaquio Ilundain y Esteban, Obispo de Orense, Vengo en nombrarle para la Iglesia y Arzobispado de Sevilla que ha de quedar vacante por traslación de Don Enrique Almaraz y Santos» ${ }^{122}$.

${ }^{120}$ El Pensamiento Navarro, 18 de noviembre de 1920, cita tomada de Laureano Tovar GonZÁLEZ, Ensayo biográfico del Emmo. Señor Cardenal Ilundain y Esteban, Obispo que fue de Orense y Arzobispo de Sevilla, o.c., p. 195.

${ }^{121}$ Cfr. Promoción del Dr. Ilundain. Nota biográfica, en BCMO VI (1921), pp. 279-280; Gaceta de Madrid 55 (24 febrero 1921).

122 Oficio regio al nuncio apostólico de Madrid. Madrid, 15 de diciembre de 1920, en ASV, Arch. Nunz. Madrid, busta 714, fasc. 1, tit. VII, f. 167; y en ff. 165r-180r aparece su proceso inquisotorial: «processus Inquisitionis super qualitatibus Illustrissimi et Reverendissimi Domini Eustachii Ilundain 
Cinco años después recibe el capelo cardenalicio. Fallecerá en Sevilla en 1937, a pesar de que fue designado para la archidiócesis de Toledo en 1927, la que rechazó por dos veces, aduciendo su falta de salud. Fue sepultado a los pies de Nuestra Señora de la Antigua, en la catedal de Sevilla. He aquí algunas consideraciones sobre su pontificado, a partir de la necrología publicada en el Boletín Eclesiástico de Sevilla: «el juicio de su pontificado se puede resumir diciendo que su paso por la diócesis de Sevilla deja una huella imborrable de ciencia divina, piedad eminente, celo prudentísimo y el más alto espíritu de justicia con que siempre vivió aureolado su nombre y actuación episcopal» ${ }^{123}$.

Esteban a Majestate Sua Catholica Ildephonso XIII, praesentati, si ita SS.mo. Domino Nostro Benedicto Papae XV placuerit, ad Ecclesiam Hispalensem vacantem per promotionem Emmi. ac Rdmi. D. D. Henrici Card. Almaraz y Santos nec non per super statu eiusdem Ecclesiae».

${ }^{123}$ Carlos Ros, Los Arzobispos de Sevilla. Luces y sombras en la sede hispalense, o.c., p. 282. 
